\title{
Splanchnic Metabolism of Free Fatty Acids and Production of Triglycerides of Very Low Density Lipoproteins in Normotriglyceridemic and Hypertriglyceridemic Humans
}

\author{
R. J. Havel, J. P. Kane, E. O. Balasse, N. Segel, and L. V. Basso \\ From the Cardiovascular Research Institute and Department of Medicine, \\ University of California School of Medicine, \\ San Francisco, California 94122
}

A B S TRACT Transport of free fatty acids from the blood into the splanchnic region and their conversion to triglycerides of very low density lipoproteins, together with estimates of splanchnic oxidation of free fatty acids to ketones and to carbon dioxide and water, have been made in the postabsorptive state in seven normolipemic subjects, six with primary endogenous hyperlipemia and one each with primary dysbetalipoproteinemia and mixed hyperlipemia. Net systemic transport of free fatty acids into the blood was the same in normolipemic and hyperlipemic groups, but a greater fraction was taken up in the splanchnic region in the latter. Transport into the blood in very low density lipoproteins of triglyceride fatty acids derived from free fatty acids was proportional and bore the same relationship to splanchnic uptake of free fatty acids in the two groups. In normolipemic subjects, near equilibration of specific activities after $4 \mathrm{hr}$ infusion of palmitate-1-14 $\mathrm{C}$ showed that almost all triglyceride fatty acids of very low density lipoproteins and acetoacetate were derived from free fatty acids taken up in the splanchnic region. In the hyperlipemic subjects, equilibration of free fatty acidcarbon with acetoacetate was almost complete, but not with triglyceride fatty acids, owing at least in part to increased pool size. Comparison of the rate of equilibra-

Portions of this work were presented at the Deuel Conference on Lipids, Carmel, Calif., 21 February 1968 (1) and at the Gordon Research Conference on Lipid Metabolism, 10 June 1968.

Dr. Kane was an Advanced Research Fellow of the American Heart Association. Dr. Balasse was a U. S. Public Health Service International Postdoctoral Research Fellow and his present address is Université Libre de Bruxelles, Belgium. Dr. Basso was a U. S. Public Health Service Postdoctoral Research Fellow. Dr. Segel's present address is Queen Elizabeth Hospital, Birmingham, England.

Received for publication 9 February 1970 and in revised form 6 May 1970. tion of triglyceride fatty acids $-{ }^{14} \mathrm{C}$ with rate of inflow transport from the splanchnic region, together with other data, indicated that most of the circulating triglyceride fatty acids of very low density lipoproteins in hyperlipemic subjects were also derived from free fatty acids. Although mean inflow transport of triglyceride fatty acids was greater in the hyperlipemic subjects, it correlated poorly with their concentration and it appeared that efficiency of mechanisms for extrahepatic removal must be a major determinant of the concentration of triglycerides in blood plasma of the normolipemic as well as the hyperlipemic subjects. Estimates of splanchnic respiratory quotient supported the concept that oxidation of free fatty acids accounts for almost all of splanchnic oxygen consumption in the postabsorptive state. Splanchnic oxygen consumption was greater in the hyperlipemics, but fractional oxidation of free fatty acids to ketones was higher in normolipemic subjects. Calculations of splanchnic balance indicate that a larger fraction of free fatty acids was stored in lipids of splanchnic tissues in the hyperlipemics. No differences were found between the two groups in net splanchnic transport of glucose, lactate, or glycerol.

\section{INTRODUCTION}

The liver is a major site of removal of free fatty acids (FFA) from the blood. In the postabsorptive state, FFA are presumed to be the principal substrate for its oxidative metabolism (2) and are virtually the sole precursor of triglyceride fatty acids (TGFA) secreted from the liver into the blood (3-5). Alterations in hepatic metabolism of FFA may be related causally to the metabolic derangements of diabetes mellitus, fatty infiltration of the liver, and various hyperlipemias. A variety of approaches have been used to evaluate such 
TABLE I

Characterization

\begin{tabular}{|c|c|c|c|c|c|c|c|}
\hline Subject & Age & Sex & Height & Weight & $\begin{array}{c}\text { Surface } \\
\text { area }\end{array}$ & $\begin{array}{l}\text { Ponderal } \\
\text { index }\end{array}$ & $\begin{array}{l}\text { Glucose } \\
\text { tolerance }\end{array}$ \\
\hline & $y r$ & & $\mathrm{~cm}$ & kg & $m^{2}$ & $\frac{\text { Height (inches) }}{\text { weight }(\mathrm{lb} .)^{\frac{1}{t}}}$ & $k$ \\
\hline \multicolumn{8}{|c|}{ Normolipemic } \\
\hline F. G. & 23 & M & 186 & 76.4 & 2.00 & 13.3 & - \\
\hline L. H. & 24 & M & 185 & 83.2 & 2.07 & 12.8 & - \\
\hline R. R. & 23 & M & 177 & 70.8 & 1.88 & 12.9 & - \\
\hline G. T. & 24 & M & 181 & 78.7 & 2.00 & 12.8 & - \\
\hline W. T. & 47 & M & 174 & 56.7 & 1.69 & 13.7 & - \\
\hline G. I. & 38 & M & 170 & 85.1 & 1.97 & 11.7 & 1.67 \\
\hline D. C. & 59 & $\mathrm{~F}$ & 161 & 71.0 & 1.75 & 11.8 & 0.77 \\
\hline \multicolumn{8}{|c|}{ Hyperlipemic } \\
\hline C. S. & 43 & $\mathrm{~F}$ & 158 & 67.4 & 1.69 & 11.8 & 1.74 \\
\hline A. F. & 57 & $\mathrm{~F}$ & 158 & 91.4 & 1.92 & 10.6 & 0.92 \\
\hline E. J. & 48 & $\mathrm{~F}$ & 165 & 68.2 & 1.75 & 12.2 & 0.83 \\
\hline G. S. & 40 & $\mathrm{~F}$ & 155 & 72.1 & 1.72 & 11.3 & 1.01 \\
\hline M. G. & 39 & M & 176 & 72.3 & 1.88 & 12.8 & 1.74 \\
\hline A. S. & 49 & M & 177 & 84.3 & 2.02 & 12.2 & 1.99 \\
\hline D. A. & 31 & M & 173 & 93.4 & 2.08 & 11.6 & - \\
\hline A. $\mathrm{Fr}$. & 51 & M & 163 & 91.2 & 1.97 & 11.0 & 0.82 \\
\hline
\end{tabular}

* Methods: cholesterol (7); phospholipids (8); triglycerides (9); protein (10).

derangements in experimental animals and in man, but there has been no concerted effort to quantify the hepatic uptake and metabolic conversions of FFA directly and under ordinary conditions in vivo.

Recent studies in dogs with normal and accelerated rates of fat mobilization (6) have shown that certain aspects of hepatic metabolism of FFA can be quantified during continuous intravenous infusion of tracer FFA by sampling arterial and hepatic venous blood even though most of the blood entering the liver is derived from the portal vein. This conclusion is derived chiefly from two observations: (a) the liver takes up titratable FFA and palmitate ${ }^{14} \mathrm{C}$ in substantial amounts from the blood but is not itself a source of circulating FFA; and (b) two of the major metabolic products of FFA which enter hepatic venous blood from the splanchnic region-triglycerides and ketone bodies-are synthesized solely in the liver. These studies also showed that liver accounts for about $75 \%$ of the FFA removed from the blood in the splanchnic region.

On the basis of this information, we have undertaken studies of the splanchnic uptake of FFA and of the conversion of the FFA to major metabolic products in man. Here we report results of our initial studies in healthy subjects and subjects with primary endogenous hyperlipemias. The data obtained provide quantitative information concerning the contribution of FFA to hepatic oxidative metabolism in humans fasted overnight and the first direct and unambiguous measurements of conversion of FFA taken up in the splanchnic region to plasma TGFA which are shown to be secreted almost entirely in very low density lipoproteins (VLDL). They also indicate that conversion of FFA to TGFA in liver is not altered in states of primary endogenous hyperlipemia and suggest that impaired extrahepatic metabolism of VLDL triglycerides has a dominant role in the pathogenesis of these common metabolic disorders.

\section{METHODS}

Experimental subjects (Table I). The seven normolipemic subjects included four healthy, nonobese men, 20-30 yr old, a 47 yr old man with chronic asthmatic bronchitis, and a $38 \mathrm{yr}$ old man and a $59 \mathrm{yr}$ old woman who were moderately obese. These subjects had no clinical evidence of metabolic disease and had normal serum concentrations of creatinine, uric acid, and protein-bound iodine. Tests of hepatic function (serum albumin, globulin, alkaline phosphatase, glutamic-oxaloacetic transaminase, and bilirubin) were normal. Serum concentrations of lipids and composition of VLDL were also in the generally accepted range of normal. The eight hyperlipemic subjects included four men and four women. Six had VLDL of normal composition and electrophoretic mobility (primary endogenous hyperlipemia). One man (M. G.) had VLDL which were abnormally rich in cholesterol and poor in triglycerides and a broad-beta band upon lipoprotein electrophoresis in agarose gel (primary dysbetalipoproteinemia). Another man (A. Fr.) 


\begin{tabular}{|c|c|c|c|c|c|c|c|}
\hline \multicolumn{3}{|c|}{ Serum lipid concentrations* } & \multicolumn{5}{|c|}{ Per cent composition of very low density lipoproteins* } \\
\hline $\begin{array}{c}\text { Total } \\
\text { cholesterol }\end{array}$ & Phospholipids & Triglycerides & $\begin{array}{c}\text { Cholesterol } \\
\text { esters }\end{array}$ & $\begin{array}{c}\text { Free } \\
\text { cholesterol }\end{array}$ & Phospholipids & Triglycerides & Protein \\
\hline & $m g / 100 m l$ & & & & $\%$ & & \\
\hline 174 & 141 & 65 & - & - & - & - & - \\
\hline 260 & 192 & 110 & - & - & - & - & - \\
\hline 234 & 182 & 65 & 17 & 7 & 20 & 50 & 7 \\
\hline 206 & 166 & 68 & 17 & 7 & 23 & 46 & 7 \\
\hline 176 & 182 & 61 & 17 & 6 & 14 & 57 & 7 \\
\hline 213 & 192 & 115 & 15 & 6 & 16 & 57 & 7 \\
\hline 277 & 257 & 67 & - & - & - & - & - \\
\hline 249 & 235 & 366 & 14 & 8 & 16 & 55 & 7 \\
\hline 411 & 561 & 560 & 15 & 9 & 18 & 50 & 9 \\
\hline 357 & 367 & 484 & 20 & 7 & 21 & 44 & 8 \\
\hline 223 & 301 & 206 & 15 & 6 & 16 & 57 & 7 \\
\hline 441 & 276 & 333 & 28 & 10 & 17 & 37 & 8 \\
\hline 204 & 190 & 194 & 11 & 6 & 19 & 57 & 7 \\
\hline 380 & 390 & 842 & 17 & 7 & 15 & 54 & 7 \\
\hline 154 & 215 & 550 & 10 & 7 & 18 & 58 & 6 \\
\hline
\end{tabular}

sometimes had chylomicronemia (primary mixed hyperlipemia) but it was not present at the time of study. A. Fr. had had gout for $15 \mathrm{yr}$, treated with probenecid, and serum uric acid was increased in C. S. and A. S.; serum creatinine, protein-bound iodine, resting electrocardiogram, and $\mathrm{X}$-ray of the chest were normal in all. Tests of hepatic function were normal in all except for slight increases of alkaline phosphatase in M. G., A. S., and A. Fr. Fasting blood glucose concentration was normal in all but $\mathrm{A}$. Fr., who had mild fasting hyperglycemia on the day of study. Intravenous glucose tolerance $(0.5 \mathrm{~g} / \mathrm{kg}$ ) was reduced ( $k$ values below 1.00) in A. F., E. J., A. Fr., and control subject D. C. It was not tested in the thin normolipemic subjects or in hyperlipemic subject D. A. Oral glucose tolerance was normal in D. A. All hyperlipemic subjects except G. S. had been followed for 1 yr or more. Most were on "diabetic" diets with restriction of simple sugars, but none had lost appreciable weight or was taking drugs known to affect plasma lipids in the 2 months before study. None had unusually large intake of alcoholic beverages. All subjects were admitted to the hospital at least 3 days before splanchnic metabolism was studied and maintained on diets calculated to maintain weight and containing the following distribution of calories: $16 \%$ protein, $40 \%$ carbohydrate, and $44 \%$ fat. The dinner on the night preceding the study contained less than $5 \mathrm{~g}$ of fat with carbohydrate added to maintain constant caloric intake.

Experimental procedure. The subjects were brought to the laboratory without premedication $14 \mathrm{hr}$ after the last meal and rested on a fluoroscopy table. Indwelling catheters of Teflon were inserted percutaneously into the left brachial artery and an antecubital or forearm vein under local anesthesia with lidocaine. A small incision was made over the right basilic vein in the antecubital fossa and a No. 7 or 8
Teflon-lined NIH catheter was passed to the main right hepatic vein under fluoroscopic control. Albumin- ${ }^{120} \mathrm{I}$ was injected intravenously for estimation of plasma volume and blood samples were taken for analysis 10 and $30 \mathrm{~min}$ later. A constant infusion of palmitate- $1-{ }^{14} \mathrm{C}$-albumin complex $(-0.25 \mu \mathrm{Ci} / \mathrm{min})$ and indocyanine green $(-0.65 \mathrm{mg} / \mathrm{min})$ was begun through the catheter in the arm vein. A slow infusion of $0.15 \mathrm{M}$ sodium chloride solution was given through the hepatic venous catheter and it and the arterial catheter were flushed frequently with the same solution. No heparin was used. Every effort was made to maintain a quiet and relaxed atmosphere and most subjects listened to music during the procedure. During the $4 \mathrm{hr}$ of study, discomfort was minimized by occasional infiltration of lidocaine into the site of the incision and the subjects were allowed to bend their knees except for a period of $5 \mathrm{~min}$ before each blood sampling. The blood samples were taken from the arterial and hepatic venous catheters at 20- to 30 -min intervals in the following order: $7 \mathrm{ml}$ into heparinized, oiled syringes for analysis of blood gases and volume of packed red blood cells; $18 \mathrm{ml}$ into dry, glass syringes which was transferred to test tubes containing $0.01 \mathrm{ml}$ of heparin (10 $\mathrm{U})$ per $\mathrm{ml}$ blood and chilled in ice; duplicate samples of $2 \frac{1}{2} \mathrm{ml}$ into $3-\mathrm{ml}$ plastic syringes for estimation of ${ }^{14} \mathrm{CO}_{2}$ and $6 \mathrm{ml}$ for measurement of indocyanine green which was placed into a plain test tube and allowed to clot. Blood was replaced with $0.15 \mathrm{M}$ sodium chloride solution.

Analytical methods. Triplicate $0.050 \mathrm{ml}$ samples were taken from the heparinized blood for analysis of glucose (11) and $3 \mathrm{ml}$ was deproteinized in $3 \mathrm{ml}$ of $30 \%$ perchloric acid for estimation of glycerol (12), acetoacetate and $\beta$-hydroxybutyrate (6), and lactate (13) by enzymatic microfluorimetric procedures. Acetoacetate was assayed within $12 \mathrm{hr}$. The remainder of the heparinized blood was centri- 
fuged at $1000 \mathrm{~g}$ for $20 \mathrm{~min}$ at $3^{\circ} \mathrm{C}$. Duplicate $1 \mathrm{ml}$ samples were taken for extraction of lipids in Dole's mixture and $4 \mathrm{ml}$ was taken for separation of VLDL (6). Total protein was estimated on $0.1 \mathrm{ml}$ samples by the biuret method (14). FFA were estimated in the washed heptane extract from Dole's mixture and the FFA and TGFA were separated (15). The entire fraction containing FFA and onehalf of that containing TGFA were taken for estimation of ${ }^{14} \mathrm{C}(6)$. The remainder of the TGFA fraction was used for estimation of glyceride-glycerol (9). VLDL separated (from $4 \mathrm{ml}$ of plasma) in the preparative ultracentrifuge were transferred quantitatively into $40 \mathrm{ml}$ of chloroformmethanol, $2: 1$; after $2 \mathrm{hr}$ or more, $40 \mathrm{ml}$ of $0.005 \mathrm{~N}$ sulfuric acid was added. The chloroform phase was used for analysis of ${ }^{14} \mathrm{C}$ and glyceride-glycerol. $\mathrm{CO}_{2}$ and oxygen in blood were measured in duplicate by the method of van Slyke and Neill (16) and ${ }^{14} \mathrm{CO}_{2}$ in duplicate by a modification (6) of the method of Buhler (17). When necessary, lactescent VLDL were removed (6) before analysis of indocyanine green in serum (18).

Materials. Palmitate- $1-{ }^{14} \mathrm{C}(9 \mu \mathrm{Ci} / \mu$ mole $)$ was obtained from New England Nuclear and complexed with human serum albumin (6). Over $99 \%$ of the ${ }^{14} \mathrm{C}$ had the typical solubility characteristics of a long-chain fatty acid. Indocyanine green was obtained as Cardiogreen (Hynson, Westcott, \& Dunning, Inc.).

Calculations. The general equations used have been described (6). Values for conversion of palmitate-1 $-{ }^{14} \mathrm{C}$ to TGFA in plasma and in VLDL were taken from the mean values of five samples obtained in the steady state from
120 to $240 \mathrm{~min}$ after starting the isotopic infusion. In other cases, values given are means of eight or nine samples except for oxygen and carbon dioxide in blood (five or six samples) and indocyanine green (six samples). Replicate values, obtained for all measurements except those for VLDL, generally agreed to within $\pm 3 \%$.

In dogs receiving a constant intravenous infusion of palmitate- $1-{ }^{14} \mathrm{C}$, the steady-state specific activity of FFA in portal venous blood was about $10 \%$ lower than that in arterial blood, while the composition of FFA was identical in the two sites. This indicates that in the extrahepatic splanchnic region, FFA are not only taken up into tissues but also released into the blood (presumably from mesenteric and omental adipose tissue). In contrast, the specific activity of FFA in hepatic venous blood was not distinguishable from that entering the liver, indicating that FFA are not released from the liver. Under the assumption that FFA released in the extrahepatic splanchnic region contain no ${ }^{14} \mathrm{C}$, net release of FFA from the region drained by the portal vein and from the liver can readily be calculated (6). The difference between these two values represents the quantity of FFA released from the extrahepatic region which is taken up in the liver and thus does not reach the systemic circulation. In the present studies, only arterial and hepatic venous blood was sampled so that values for uptake of FFA based upon extraction fraction of palmitate${ }^{14} \mathrm{C}$ in the splanchnic region underestimate total splanchnic uptake. However, from the reduction in specific activity of FFA between artery and hepatic vein, net splanchnic release of FFA can be calculated.

TABLE II

Arterial Concentrations and other Values Obtained during Study of Splanchnic Metabolism

\begin{tabular}{|c|c|c|c|c|c|c|c|c|c|c|c|c|}
\hline \multirow[b]{3}{*}{ Subject } & \multirow[b]{3}{*}{$\begin{array}{l}\text { Plasma } \\
\text { volume }\end{array}$} & \multirow{2}{*}{\multicolumn{3}{|c|}{ Splanchnic }} & \multicolumn{8}{|c|}{ Arterial concentrations } \\
\hline & & & & & \multicolumn{3}{|c|}{ Plasma } & \multicolumn{5}{|c|}{ Blood } \\
\hline & & $\begin{array}{l}\text { Plasma } \\
\text { flow }\end{array}$ & $\begin{array}{l}\text { consump- } \\
\text { tion }\end{array}$ & $\mathbf{R Q}$ & FFA & $\begin{array}{l}\text { TGFA } \\
\text { (plasma) }\end{array}$ & $\begin{array}{c}\text { TGFA } \\
(\text { VLDL) }\end{array}$ & $\begin{array}{l}\text { Aceto- } \\
\text { acetate }\end{array}$ & $\begin{array}{c}\beta \text {-Hydroxy- } \\
\text { butyrate }\end{array}$ & Glucose & Glycerol & Lactate \\
\hline & $\begin{array}{c}\text { liters/ } \\
m^{2}\end{array}$ & $\begin{array}{c}m l / \\
m i n \cdot m^{2}\end{array}$ & $\begin{array}{c}\text { mmoles } / \\
m i n \cdot m^{2}\end{array}$ & & & & & $\mu m$ & $l e s / m l$ & & & \\
\hline \multicolumn{13}{|c|}{ Normolipemic } \\
\hline F. G. & 1.73 & 459 & 1.38 & - & 1.03 & 1.50 & 0.82 & 0.184 & 0.296 & 5.8 & 0.067 & 0.136 \\
\hline L. H. & 1.60 & 380 & 1.27 & - & 0.69 & 2.75 & 2.00 & 0.120 & 0.123 & 5.8 & 0.046 & 0.268 \\
\hline R. $\mathbf{R}$. & 1.54 & 304 & 1.52 & - & 0.95 & 1.33 & 0.66 & 0.270 & 0.366 & 6.1 & 0.058 & 0.587 \\
\hline G. T. & 1.75 & 412 & 1.14 & 0.35 & 0.72 & 1.54 & 1.03 & 0.165 & 0.206 & 5.3 & 0.078 & 0.346 \\
\hline W. T. & 1.42 & 446 & 1.82 & 0.54 & 0.54 & 2.26 & 1.75 & 0.208 & 0.349 & 5.1 & 0.050 & 0.196 \\
\hline G. I. & 1.43 & 410 & 1.27 & 0.46 & 0.60 & 3.96 & 2.95 & 0.077 & 0.198 & 6.5 & 0.060 & 0.366 \\
\hline D. C. & 1.30 & 321 & 1.07 & - & 0.90 & 2.25 & 1.23 & 0.235 & 0.155 & 6.0 & 0.065 & - \\
\hline Mean & 1.55 & 390 & 1.35 & 0.45 & 0.78 & 2.23 & 1.49 & 0.178 & 0.242 & 5.8 & 0.055 & 0.316 \\
\hline SEM & 0.063 & 22 & 0.096 & 0.055 & 0.065 & 0.32 & 0.28 & 0.025 & 0.036 & 0.17 & 0.003 & 0.063 \\
\hline \multicolumn{13}{|c|}{ Hyperlipemic } \\
\hline C. $\mathbf{S}$. & 1.60 & 560 & 1.51 & - & 0.75 & 8.83 & 6.92 & 0.116 & 0.262 & 5.5 & 0.070 & 0.370 \\
\hline A. F. & 1.49 & 437 & 1.77 & 0.43 & 1.18 & 18.47 & 13.77 & 0.038 & 0.160 & 5.7 & 0.104 & 0.741 \\
\hline E. J. & 1.51 & 405 & 1.68 & 0.34 & 0.76 & 15.88 & 14.95 & 0.112 & 0.287 & 5.4 & 0.044 & 0.666 \\
\hline G. S. & 1.56 & 458 & 1.51 & 0.58 & 0.80 & 7.4 .5 & 6.18 & 0.125 & 0.140 & 5.9 & 0.079 & 0.594 \\
\hline M. G. & 1.43 & 380 & 1.78 & 0.41 & 0.71 & 13.80 & 9.50 & 0.17 .5 & 0.163 & 5.8 & 0.077 & 0.341 \\
\hline A. S. & 1.13 & 338 & 1.33 & 0.50 & 0.57 & 6.55 & 5.47 & 0.065 & 0.377 & 6.5 & 0.057 & 0.224 \\
\hline D. A. & 1.44 & 5.30 & 2.16 & 0.51 & 0.65 & 27.43 & 27.76 & 0.111 & 0.093 & 5.8 & - & 0.325 \\
\hline A. Fr. & 1.45 & 360 & 1.97 & 0.60 & 0.56 & 17.21 & 13.01 & 0.136 & 0.142 & 7.6 & 0.051 & 0.265 \\
\hline Mean & 1.45 & 434 & 1.71 & 0.48 & 0.75 & 14.4 .5 & 12.20 & 0.110 & 0.204 & 6.0 & 0.069 & 0.440 \\
\hline SEM & 0.050 & 28 & 0.095 & 0.035 & 0.069 & 2.45 & 2.57 & 0.015 & 0.034 & 0.26 & 0.007 & $0.06)$ \\
\hline$P$ & NS & NS & 0.05 & NS & NS & $<0.01$ & $<0.01$ & 0.05 & NS & NS & NS & NS \\
\hline
\end{tabular}



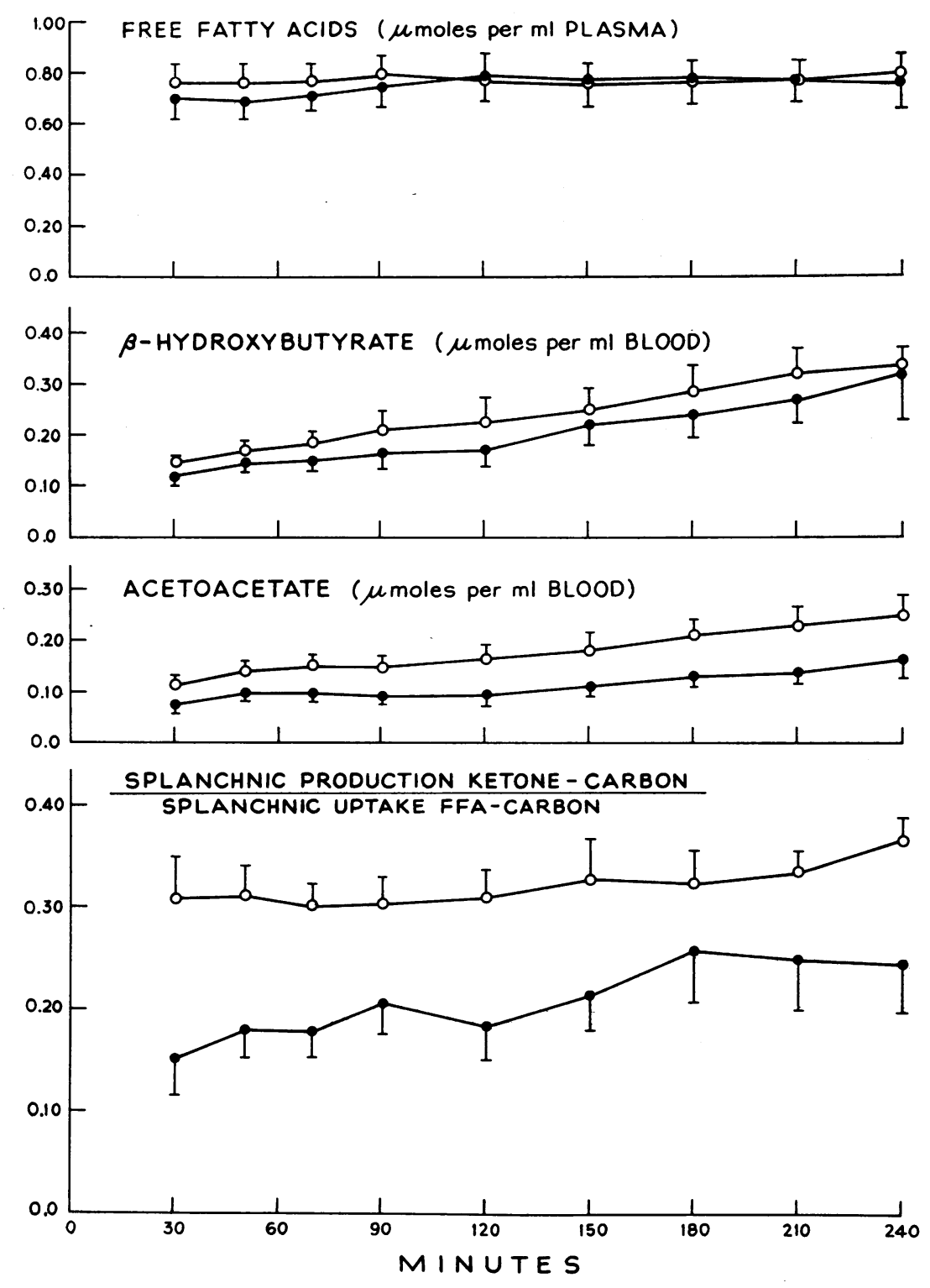

FIGURE 1 Arterial concentrations of FFA and ketones and relation between splanchnic uptake of FFA and production of ketones during study of splanchnic metabolism in normolipemic (open circles) and hyperlipemic subjects (closed circles). Bars indicate SEM.

(a) Net splanchnic release of FFA ( $\mu$ moles per $\mathrm{ml}$ plasma $)=$ arterial concentration $\times$ extraction fraction of palmitate- ${ }^{14} \mathrm{C}-$ (arterial concentration - hepatic venous concentration).

In the studies in dogs, the hepatic extraction fraction for FFA averaged about $80 \%$ (range $73-84 \%$ ) of that for the entire splanchnic region. If it is assumed that this value also applies to man, the total splanchnic release of FFA can be calculated and, by difference, hepatic uptake of FFA released from the extrahepatic splanchnic region can be estimated. (b) Total splanchnic release of FFA ( $\mu$ moles per $\mathrm{ml}$ plasma) $=$

net splanchnic release

$\overline{1-\left(\text { observed extraction fraction of palmitate }-{ }^{10} \mathrm{C} \times 0.8\right)}$

(c) Hepatic uptake of FFA derived from FFA entering portal venous blood from extrahepatic region = equation $b$ - equation $a$.

Differences of mean values between groups have been evaluated by the Wilcoxon-White two-sample ranks test (19). Linear regressions have been calculated by the 
method of least squares and their significance tested by estimating the correlation coefficient, " $r$."

\section{RESULTS}

Values for volume of packed red blood cells and for concentration of total protein of plasma in arterial and hepatic venous samples differed by no more than $2 \%$. The normolipemic and hyperlipemic subjects had generally similar levels of FFA, glycerol, and $\beta$-hydroxybutyrate (Table II). However, the concentration of acetoacetate was lower in the hyperlipemic group. The concentrations of FFA and glycerol remained stable during the $4 \mathrm{hr}$ period of study, but ketone levels rose gradually (Fig. 1). Concentrations of glucose and lactate were similar in the two groups, except for mild fasting hyperglycemia in A.Fr. The concentration of VLDL-TGFA varied considerably in both groups of subjects and was on the average 8 times higher in the hyperlipemic subjects. Comparison of TGFA concentrations in plasma and VLDL shows that almost the entire increase in TGFA of hyperlipemics was in VLDL.

Blood flow to the splanchnic region was in the expected range and was similar in the two groups, but splanchnic oxygen consumption was higher (by 27\%) in the hyperlipemic subjects. Splanchnic R.Q. was measured in only three of the normolipemic subjects, but was in the same range as that observed in the hyperlipemics. The relationship of over-all splanchnic oxidative metabolism to that of FFA will be considered later.

Net transport of FFA into arterial blood plasma was generally in the high normal range and was similar in the two groups (Table III). The turnover rate of FFA was in the range expected for rested, postabsorptive subjects (15). A significantly larger amount of FFA

TABLE III

Metabolism of Free Fatty Acids

\begin{tabular}{|c|c|c|c|c|c|c|c|c|c|}
\hline \multirow[b]{2}{*}{ Subject } & \multirow[b]{2}{*}{$\begin{array}{l}\text { Arterial net } \\
\text { inflow } \\
\text { transport }\end{array}$} & \multirow[b]{2}{*}{$\begin{array}{l}\text { Turnover } \\
\text { rate }\end{array}$} & \multicolumn{7}{|c|}{ Splanchnic metabolism } \\
\hline & & & $\begin{array}{l}\text { Extraction } \\
\text { fraction }\end{array}$ & $\begin{array}{l}\text { Uptake } \\
\text { (arterial) }\end{array}$ & $\begin{array}{c}\text { Net } \\
\text { release* }\end{array}$ & $\begin{array}{l}\text { Uptake } \\
\text { (from } \\
\text { portal } \\
\text { inflow) } \ddagger\end{array}$ & $\begin{array}{c}\text { Total } \\
\text { uptake } \\
\text { (arterial } \\
+ \text { portal)\& }\end{array}$ & $\begin{array}{c}\text { Total net } \\
\text { inflow } \\
\text { transport } \\
\text { (arterial } \\
+ \text { portal)\& }\end{array}$ & $\begin{array}{l}\text { (Total splanchnic } \\
\text { uptake)/ } \\
\text { (total net } \\
\text { inflow transport) }\end{array}$ \\
\hline & $\begin{array}{l}\mu m o l e s / \\
\min \cdot m^{2}\end{array}$ & $\min ^{-1}$ & \multicolumn{7}{|c|}{$\mu \mathrm{moles} / \mathrm{min} \cdot \mathrm{m}^{2}$} \\
\hline \multicolumn{10}{|c|}{ Normolipemic } \\
\hline F. G. & 410 & 0.218 & 0.30 & 149 & 69 & 22 & 171 & 432 & 0.40 \\
\hline L. H. & 246 & 0.218 & 0.32 & 83 & 28 & 10 & 93 & 256 & 0.36 \\
\hline R. R. & 357 & 0.248 & 0.39 & 156 & 49 & 22 & 178 & 379 & 0.47 \\
\hline G. T. & 296 & 0.232 & 0.36 & 94 & 22 & 9 & 103 & 305 & 0.34 \\
\hline W. T. & 212 & 0.277 & 0.46 & 109 & 24 & 14 & 123 & 226 & 0.54 \\
\hline G. I. & 245 & 0.297 & 0.34 & 83 & 43 & 16 & 99 & 261 & 0.38 \\
\hline D. C. & 318 & 0.270 & 0.41 & 132 & 19 & 9 & 141 & 327 & 0.43 \\
\hline Mean & 298 & 0.251 & 0.37 & 115 & 36 & 15 & 130 & 312 & 0.42 \\
\hline SEM & 26 & 0.012 & 0.021 & 11.6 & 6.9 & 2.2 & 13.1 & 27.7 & 0.03 \\
\hline \multicolumn{10}{|c|}{ Hyperlipemic } \\
\hline C. S. & 343 & 0.285 & 0.47 & 153 & 34 & 15 & 168 & 358 & 0.47 \\
\hline A. F. & 486 & 0.273 & 0.46 & 236 & 10 & 7 & 243 & 493 & 0.49 \\
\hline E. J. & 282 & 0.242 & 0.52 & 189 & 107 & 76 & 265 & 358 & 0.74 \\
\hline G. S. & 340 & 0.269 & 0.48 & 174 & 52 & 32 & 206 & 372 & 0.56 \\
\hline M. G. & 291 & 0.286 & 0.49 & 134 & 61 & 39 & 173 & 330 & 0.52 \\
\hline A. S. & 224 & 0.344 & 0.47 & 91 & 95 & 57 & 148 & 281 & 0.53 \\
\hline D. A. & 269 & 0.292 & 0.43 & 145 & 82 & 43 & 188 & 312 & 0.60 \\
\hline A. Fr. & 234 & 0.281 & 0.63 & 129 & 42 & 42 & 171 & 276 & 0.62 \\
\hline Mean & 309 & 0.284 & 0.48 & 156 & 60 & 39 & 195 & 348 & 0.57 \\
\hline SEM & 30 & 0.010 & 0.026 & 16 & 12 & 7.8 & 14.2 & 24.3 & 0.03 \\
\hline$P$ & NS & NS & $<0.01$ & NS & NS & 0.05 & $<0.05$ & NS & $<0.01$ \\
\hline
\end{tabular}

* From equation 1 (see Methods) $\times$ hepatic plasma flow.

$\ddagger$ From equation 3 (see Methods) $\times$ hepatic plasma flow.

\& "Total" refers to uptake or transport from arterial blood plus that entering liver from extrahepatic splanchnic region. 


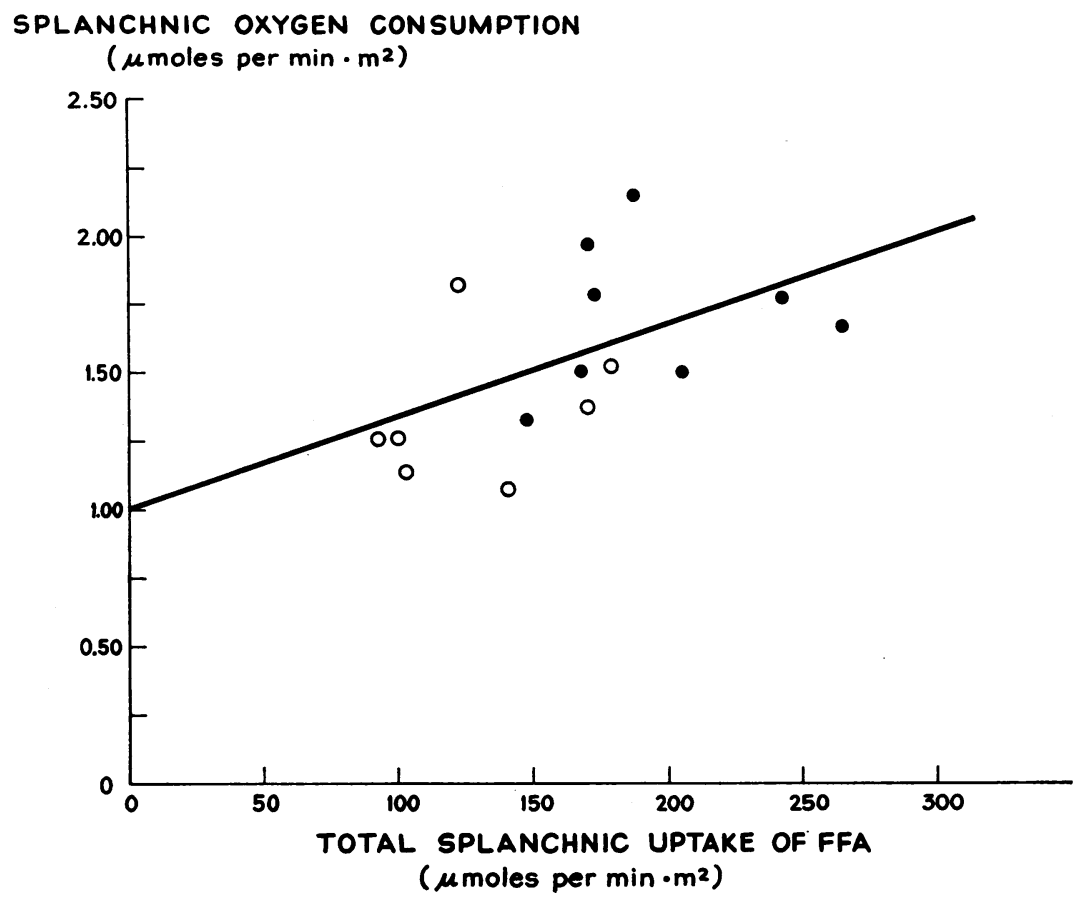

FIGURE 2 Relation between uptake of FFA and oxygen consumption in splanchnic region in normolipemic (open circles) and hyperlipemic subjects (closed circles). Regression coefficient $=0.00327, r=0.52 ; 0.05>P>0.02$.

was taken up from the blood in the splanchnic region in hyperlipemic subjects. This was related to two factors: (a) a larger extraction fraction of FFA entering from arterial blood ( 0.48 vs. 0.37 ) and (b) a larger release of FFA from the extrahepatic splanchnic region into the portal venous blood which was taken up, in part, in the liver. The extraction fraction was well correlated with the fraction of FFA taken up in the splanchnic region $(y=0.093+0.84 x, r=0.77,-P<0.001)$. Net inflow transport of FFA into arterial blood underestimates "total" net inflow transport to the extent that FFA, released from the extrahepatic splanchnic region, are taken up directly in the liver. This underestimate amounted to an average of $5 \%$ in the normolipemic and $11 \%$ in the hyperlipemic subjects. Although splanchnic release of FFA was significantly greater in the hyperlipemics, it did not correlate with extent of obesity as estimated from the ponderal index. The greater splanchnic uptake of FFA in hyperlipemic subjects amounted to more than half (mean value $57 \%$ ) of net inflow transport (including FFA released from the extrahepatic splanchnic region which were taken up in the liver) as compared with a value of $42 \%$ in the normolipemics. When all subjects were considered together, splanchnic uptake of FFA was directly related to splanchnic oxygen consumption (Fig. 2). Splanchnic uptake of FFA was also a function of net inflow transport, but the relationship differed in the two groups (Fig. 3).

In all subjects, labeled TGFA appeared in hepatic venous blood plasma $30-40 \mathrm{~min}$ after infusion of palmitate- ${ }^{14} \mathrm{C}$ was begun. The rate of appearance increased rapidly at first, but no further increase in rate could be detected after $120 \mathrm{~min}$ in either the normolipemic or hyperlipemic groups (Fig. 4). The mean value between 120 and $240 \mathrm{~min}$ was therefore used to provide an estimate of the conversion of FFA to TGFA entering the blood from the splanchnic region. These estimates amount to about $17 \%$ in both groups of subjects (Table IV). This metabolic pathway thus accounted for $7-8 \%$ of FFA transported in normolipemic subjects and about $10 \%$ in hyperlipemics. Although there was appreciable individual variation, mean values for conversion of FFA to TGFA in whole plasma and in VLDL were closely similar in both groups; thus, no evidence for transport of TGFA derived from FFA into plasma low density or high density lipoproteins was obtained. In the four normolipemic subjects whose VLDL-TGFA levels were lowest, their specific activity reached a value within $10 \%$ of that of FFA in hepatic venous blood plasma (assumed to be equal to that of FFA entering the liver) after $240 \mathrm{~min}$ infusion of palmitate- ${ }^{14} \mathrm{C}$ (Table IV and Fig. 5). In the hyperlipemics, the relative specific activity of VLDL-TGFA was much lower, but in all 
these subjects as well as the other three normolipemics, ${ }^{14} \mathrm{C}$ was still accumulating at an approximately linear rate after $240 \mathrm{~min}$ (Fig. 5).

Net inflow transport of TGFA derived from FFA taken up in splanchnic tissues can be estimated directly from the values for splanchnic uptake of FFA and their fractional conversion to TGFA in plasma or VLDL (Table IV). The two estimates did not differ systematically and were closely correlated $(r=0.82, P<0.001)$. For technical reasons, the values derived from measurements of $\mathrm{TGFA}-{ }^{14} \mathrm{C}$ in whole plasma are considered to provide the best estimates of net inflow transport. These values provide a valid estimate of net inflow transport of TGFA provided there are no other precursors of plasma TGFA under the conditions of study. From the values for specific activity of FFA and VLDLTGFA, this appears to be the case in the four subjects with low concentrations of VLDL-TGFA. Additionally, inflow transport estimated from arteriovenous differences in concentration VLDL-TGFA in six of the normolipemic subjects did not differ systematically from those based on splanchnic production of labeled TGFA derived from palmitate $-{ }^{14} \mathrm{C}$. The values based upon chemical measurements are considerably less precise-since they depend on measurements of glyceride-glycerol generally differing by less than $5 \%$. The contribution of FFA to inflow transport of TGFA could not be evaluated in these ways in the hyperlipemic subjects. However, as shown in Table $\mathrm{V}$, in each of five subjects, including three hyperlipemics, in whom measurements were made at 210 and 240 min after starting infusion of palmitate${ }^{14} \mathrm{C}$, the specific activity of the carboxyl-carbon of acetoacetate was closely similar to that of hepatic venous FFA indicating that the fatty acyl CoA pool leading to acetyl CoA was essentially derived from FFA entering the liver. This suggests that any VLDL-TGFA entering plasma from liver from a source other than plasma FFA could not be in equilibrium with the fatty acyl CoA pool leading to mitochondrial beta oxidation. One additional calculation of inflow transport of TGFA was made from an estimate of the turnover rate of VLDL-TGFA, based on the rate at which specific activity of VLDL-TGFA approached that of its precursor, estimated from the specific activity of FFA in hepatic venous blood (Fig.

TOTAL SPLANCHNIC UPTAKE OF FFA

$\left(\mu\right.$ moles per $\min \cdot \mathrm{m}^{2}$ )

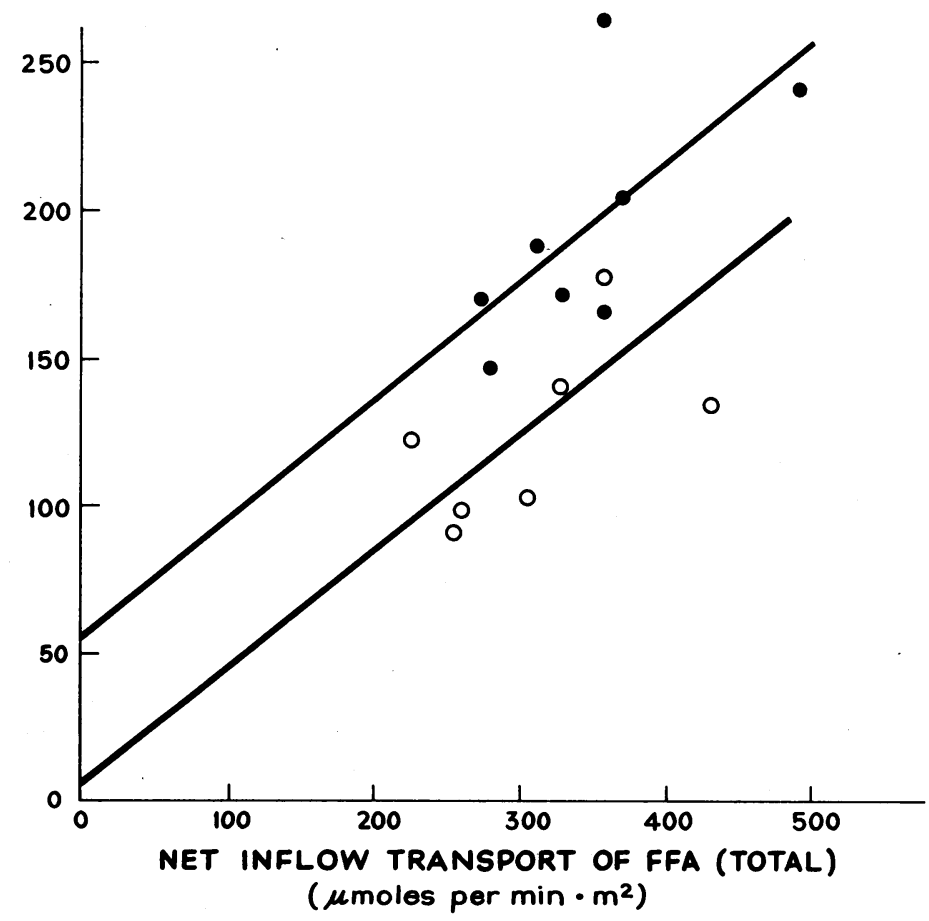

FIGURE 3 Relation between net inflow transport of FFA into arterial and portal venous blood and splanchnic uptake of FFA. The relation for normolipemic subjects (open circles, regression coefficient $=0.395, r$ $=0.84,0.02>P>0.01$ ) differs from that for hyperlipemic subjects (closed circles, regression coefficient $=0.398, r=0.68,0.10>P>0.05$ ). 


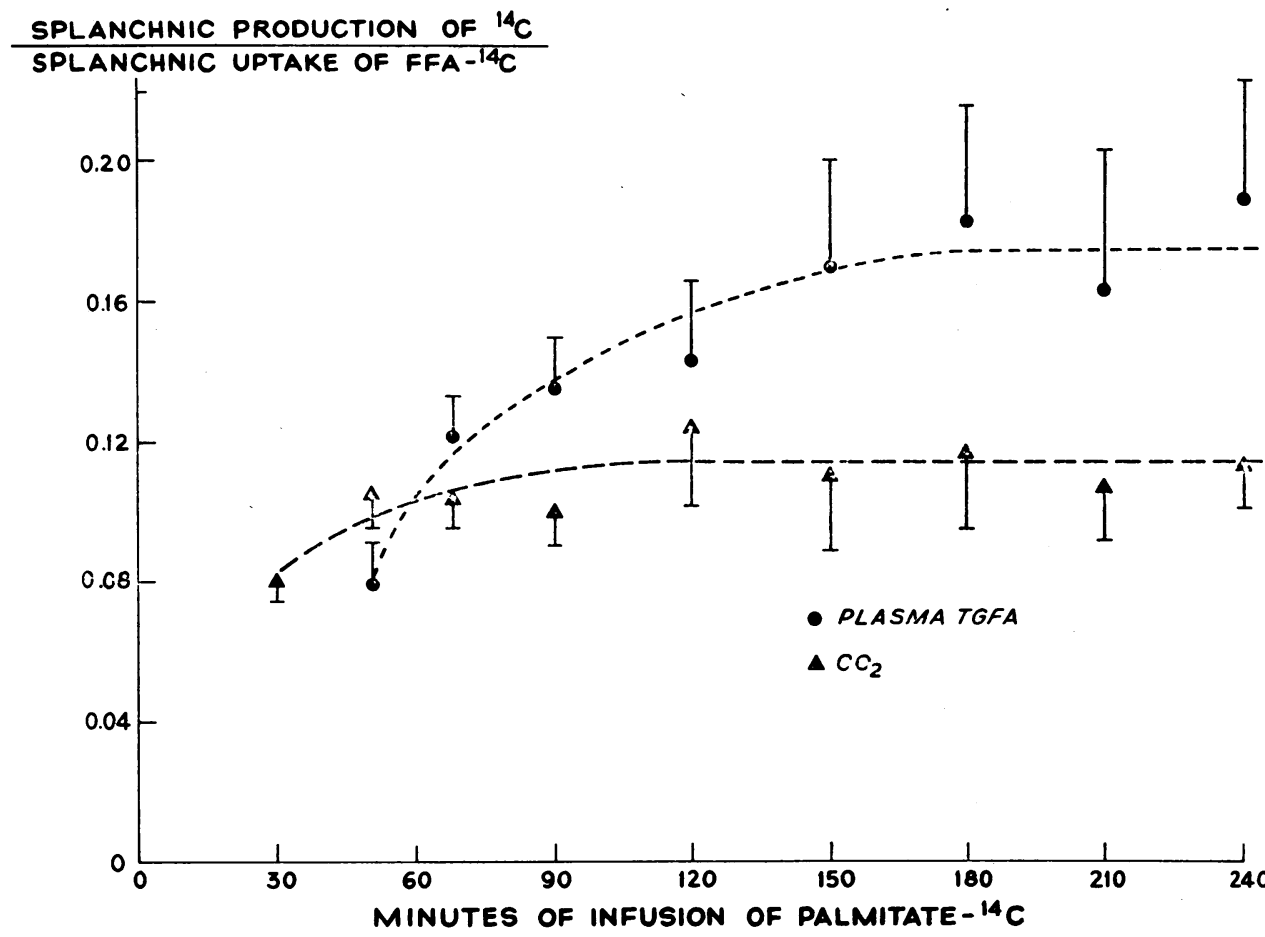

FIgURE 4 Fractional conversion of palmitate-1" $\mathrm{C}$ taken up in splanchnic region to TGFA in plasma and $\mathrm{CO}_{2}$ in blood during constant intravenous infusion of palmitate-14 $\mathrm{C}$ for $240 \mathrm{~min}$. Each value represents mean of duplicate analyses in 12-15 subjects; bars indicate SEM.

5). As shown in Fig. 4, conversion of FFA- ${ }^{14} \mathrm{C}$ to VLDL-TGFA is not constant but rather increases between 30 and $120 \mathrm{~min}$ of infusion, indicating that the precursor pool only gradually comes into equilibrium with product VLDL-TGFA. For this reason, the calculation will tend to underestimate net inflow transport. To minimize this error, the calculations were based upon values during the last hour except in those cases where the specific activity of VLDL-TGFA closely approached that of hepatic venous FFA. Underestimation of transport from FFA would also result from presence of other precursors of VLDL-TGFA (20). The values obtained with this method did not differ systematically from and correlated with $(r=0.70, P<0.01)$ those based upon measurements of arteriovenous differences of TGFA $-{ }^{14} C$. These results strongly suggest that very little VLDL-TGFA in the hyperlipemic as well as normolipemic subjects is derived from precursors other than FFA entering the liver. Mean values for net inflow transport were on the average about $50 \%$ higher in hyperlipemic subjects. This was related to increased splanchnic uptake of FFA rather than preferential conversion of FFA to VLDL-TGFA. Inflow transport of TGFA was well correlated with splanchnic uptake of FFA (Fig. 6) as well as net inflow transport of FFA $(r=0.74, P<0.01)$. In contrast, inflow transport of
TGFA was poorly correlated with their concentration (Fig. 7). Generally, for a given rate of production, hyperlipemic subjects had much higher plasma levels of VLDL-TGFA. The turnover time (reciprocal of turnover rate) of VLDL-TGFA correlated closely with their content in plasma in both normolipemic $(y=-68$ $+0.085 x, r=0.98, P<0.001)$ and hyperlipemic $(y=$ $-48+0.036 x, r=0.93, P<0.001)$ subjects as well as in the combined groups $(y=26+0.033 x, r=0.95, P<$ 0.001 ).

Splanchnic oxidative metabolism of FFA did differ in the two groups of subjects. Conversion to ketones accounted for $31 \%$ of palmitate $-{ }^{14} \mathrm{C}$ taken up in the splanchnic region in normal subjects compared with a value of $20 \%$ in the hyperlipemics (Table IV). These values underestimate the actual conversions to the extent that ketones are extracted from the blood in the extrahepatic splanchnic area. Results obtained in dogs (6) suggest that the underestimate is of the order of $20 \%$. Taken together with the probability that about $20 \%$ of splanchnic uptake of FFA is extrahepatic, this suggests that almost half of the FFA entering the livers of our normolipemic subjects and about one-third in the hyperlipemics was oxidized to ketones. During the period of study, production of acetoacetate and $\beta$-hydroxybutyrate tended to rise in the hyperlipemic groups but not in the 
controls (Fig. 1). Arterial levels of ketones, however, increased with time in both groups and this did not appear to be related to increased splanchnic production, particularly in the normolipemic group. Significant correlations were observed (Fig. 8 ) between the concentrations of acetoacetate and $\beta$-hydroxybutyrate and their production rates as well as between the ratio of $\beta$-hydroxybutyrate to acetoacetate in arterial blood and the ratio of production rates of this redox pair. These correlations did not differ significantly between the two groups of subjects. However, the concentration of ketones was directly related to ponderal index $(r=0.66$, $P<0.01)$. This was not true for production rates. Conversion of palmitate ${ }^{20} \mathrm{C}$ to $\mathrm{CO}_{2}$ appearing in hepatic venous blood was, respectively, 8 and $13 \%$ (Table IV). These values provide a minimal estimate of oxidation of FFA in the tricarboxylic acid cycle because of isotope equilibration leading especially to appearance of ${ }^{12} \mathrm{C}$ in glucose secreted from the liver (6) and because of fixation of $\mathrm{CO}_{2}$ and its appearance in urea-carbon. Alternate estimates have, therefore, been made. As shown in Table VI, the splanchnic R.Q., corrected for measured utilization of oxygen in production of acetoacetate and $\beta$-hydroxybutyrate and for estimated fixation of $\mathrm{CO}_{2}$ during production of urea $(21,22)$, averages about 0.65 in normolipemic and hyperlipemic subjects. Calculated use of oxygen in production of ketones is underestimated to the extent that ketones are taken up in splanchnic tissues. However, this fact probably does not affect the value for R.Q. since these ketones are presumably oxidized to carbon dioxide and water. On this basis, it has been assumed that all oxygen used in the splanchnic region, not attributable to oxidation of FFA to ketones, is consumed during complete oxidation of FFA. The estimated conversion of FFA to secreted products then accounts for $84 \%$ of FFA taken up in the splanchnic region in normolipemic and $68 \%$ in hyperlipemic subjects. The quantity of FFA unaccounted for (and presumably retained in splanchnic lipids) is 3 times larger in the hyperlipemic subjects.

Net splanchnic transport of carbohydrates is shown in Table VII. No systematic difference was observed between the two groups of subjects for uptake of lactate or glycerol or production of glucose. In both, uptake of lactate and glycerol-carbon were equivalent, respectively,

TABLE IV

Splanchnic Conversion of Free Fatty Acids to Metabolic Products

\begin{tabular}{|c|c|c|c|c|c|c|c|c|c|c|c|}
\hline \multirow[b]{3}{*}{ 'Subject } & & & & & \multicolumn{4}{|c|}{ Net inflow transport of TGFA } & \multirow{3}{*}{$\begin{array}{l}\text { Plasma } \\
\text { content of } \\
\text { VLDL } \\
\text { TGFA }\end{array}$} & \multirow{3}{*}{$\begin{array}{l}\text { Turnover } \\
\text { rate of } \\
\text { VLDL } \\
\text { TGFA* }\end{array}$} & \multirow{3}{*}{$\begin{array}{c}\begin{array}{c}\text { Specific activity } \\
\text { ratio: } \\
\text { VLDL-TGFAt }\end{array} \\
\frac{\text { FFA }}{}\end{array}$} \\
\hline & \multicolumn{4}{|c|}{ Per cent of FFA converted to: } & \multirow{2}{*}{$\begin{array}{l}\text { Plasma } \\
\text { radio- } \\
\text { chemical } \\
\text { production }\end{array}$} & \multicolumn{3}{|c|}{ VLDL } & & & \\
\hline & $\begin{array}{r}\text { Plasma } \\
\text { TGFA }\end{array}$ & $\begin{array}{l}\text { VLDL } \\
\text { TGFA }\end{array}$ & $\begin{array}{l}\text { Total } \\
\text { ketones }\end{array}$ & $\mathrm{CO}_{2}$ & & $\begin{array}{l}\text { chemical } \\
\text { production }\end{array}$ & $\begin{array}{l}\text { Chemical } \\
\text { production }\end{array}$ & $\begin{array}{l}\text { Isotopic } \\
\text { equilibration }\end{array}$ & & & \\
\hline & . & & & & \multicolumn{4}{|c|}{$\mu$ moles $/ \min \cdot m^{2}$} & $\begin{array}{c}\mu \text { moles/ } \\
m^{2}\end{array}$ & $\min ^{-1}$ & \\
\hline \multicolumn{12}{|c|}{ Normolipemic } \\
\hline F. G. & 16.6 & 14.1 & 24 & 5.5 & 28.4 & 24.1 & 16.1 & 26.3 & 1420 & 0.0200 & 1.00 \\
\hline L. H. & 19.3 & 19.8 & 25 & 5.0 & 18.0 & 18.4 & 17.4 & 24.3 & 3200 & 0.0056 & 0.78 \\
\hline R. $\mathbf{R}$. & 18.3 & 14.0 & 37 & 7.9 & 32.6 & 24.9 & 28.3 & 21.1 & 1020 & 0.0320 & 0.99 \\
\hline G. T. & 19.5 & 15.0 & 24 & 10.0 & 20.1 & 15.5 & 22.0 & 19.2 & 1810 & 0.0111 & 1.07 \\
\hline W. T. & 11.8 & 13.0 & 34 & 6.3 & 14.5 & 16.0 & 27.2 & 14.4 & 2480 & 0.0059 & 0.67 \\
\hline G. I. & 14.3 & 21.0 & 33 & 11.9 & 14.2 & 20.8 & - & 15.1 & 4230 & 0.0033 & 0.54 \\
\hline D. C. & 23.5 & 19.8 & 37 & 9.0 & 33.2 & 27.8 & 32.1 & 17.4 & 1620 & 0.0207 & 0.93 \\
\hline Mean & 17.6 & 16.7 & 30.6 & 7.9 & 23.0 & 21.1 & 23.9 & 19.7 & 2254 & 0.0141 & 0.85 \\
\hline SEM & 1.4 & 1.3 & 2.3 & 1.0 & 3.1 & 1.8 & 2.6 & 1.7 & 427 & 0.0040 & 0.07 \\
\hline \multicolumn{12}{|c|}{ Hyperlipemic } \\
\hline C. $\mathbf{S .}$ & 15.0 & 25.5 & 21 & - & 25.6 & 42.8 & - & 28.7 & 11100 & 0.0023 & 0.45 \\
\hline A. F. & 19.0 & - & 11 & 22.0 & 46.2 & - & - & 47.0 & 20600 & 0.0023 & 0.32 \\
\hline E. J. & 11.5 & 11.8 & 12 & 11.2 & 30.3 & 31.3 & - & 40.0 & 22600 & 0.0014 & 0.40 \\
\hline G. S. & 25.8 & 27.5 & 13 & 9.3 & 55.1 & 55.7 & - & 38.1 & 9640 & 0.0057 & 0.55 \\
\hline M. G. & 20.4 & - & 25 & 12.2 & 35.3 & - & - & 35.7 & 13600 & 0.0026 & 0.50 \\
\hline A. $\mathbf{S}$. & 15.5 & 10.8 & 27 & 10.7 & 23.0 & 16.0 & - & 19.2 & 6190 & 0.0037 & 0.45 \\
\hline D. A. & 15.3 & 13.3 & 15 & 12.2 & 28.8 & 25.0 & - & 24.2 & 40000 & 0.0007 & 0.12 \\
\hline A. Fr. & 12.8 & 13.5 & 32 & 9.6 & 21.9 & 23.1 & - & 33.7 & 18900 & 0.0012 & 0.29 \\
\hline Mean & 16.9 & 17.1 & 19.5 & 12.5 & 33.2 & 32.3 & - & 33.3 & 17829 & 0.0025 & 0.39 \\
\hline SEM & 1.6 & 3.0 & 2.8 & 1.6 & 4.2 & 6.0 & - & 3.2 & 3753 & 0.0006 & 0.05 \\
\hline$P$ & NS & NS & $<0.05$ & $<0.05$ & NS & NS & & $<0.01$ & $<0.01$ & $<0.01$ & $<0.01$ \\
\hline
\end{tabular}

* Calculated from values for inflow transport of plasma TGFA.

$\mp$ Value at $240 \mathrm{~min}$. 
to about 15 and $5 \%$ of production of glucose-carbon. Net splanchnic uptake and concentration of glycerol were well correlated $(y=0.017+0.0014 x, r=0.93$, $P<0.001)$ but this was not the case for lactate $(y=$ $0.207+0.0018 x, \quad r=0.44, P>0.10)$. Net splanchnic uptake of glycerol was also well correlated with net inflow transport of FFA $(y=2.36+0.101 x, r=0.74$, $P<0.01)$. Splanchnic production of glucose correlated directly with splanchnic oxidation of FFA (Fig. 9) but not with their uptake.
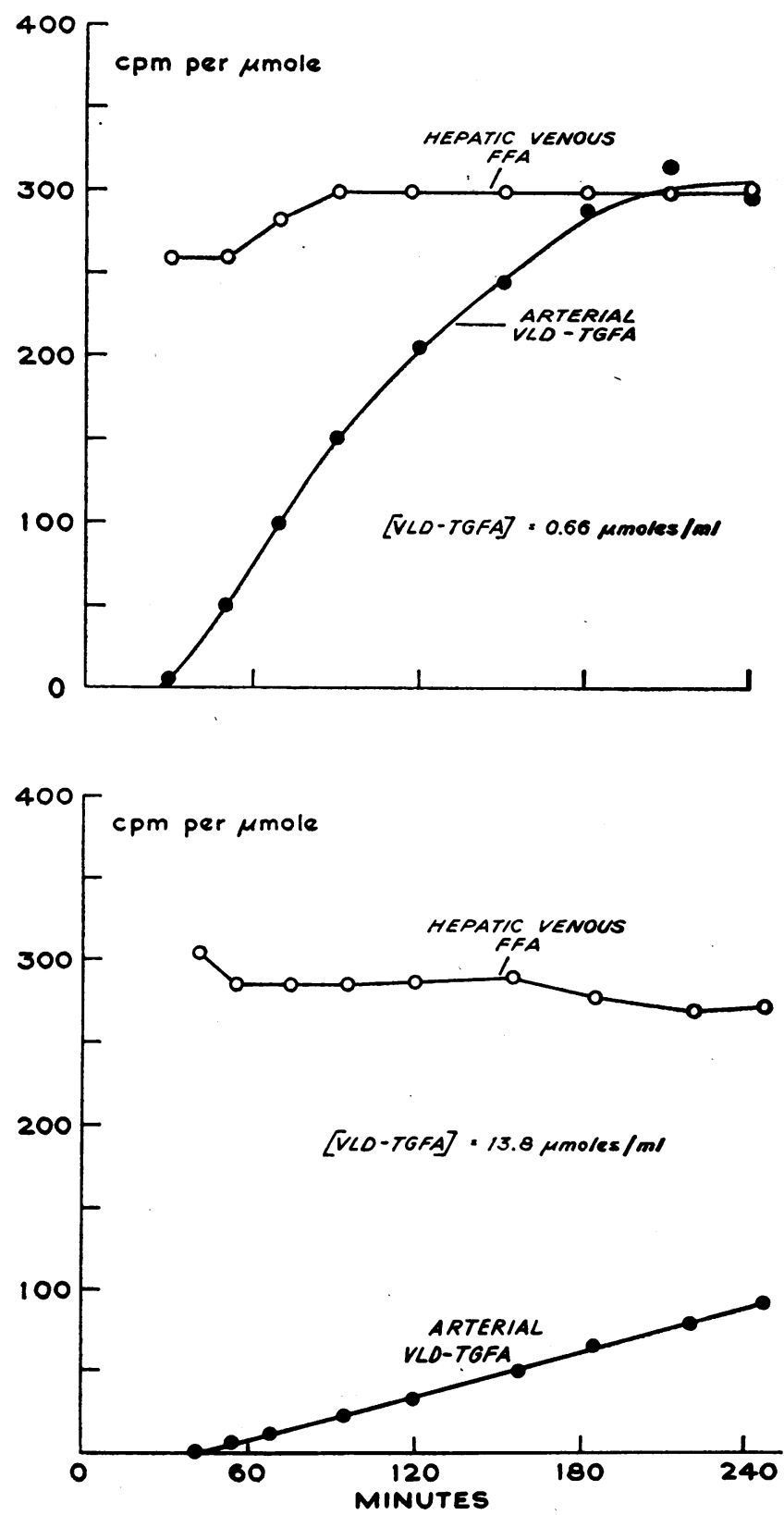

FIGURE 5 Specific activities of VLDL-TGFA and hepatic venous FFA in a normolipemic subject ( $R$. $R$., upper panel) and a hyperlipemic subject (A. F., lower panel). Turnover rates (k) calculated from relation:

$$
\frac{\text { specific activity TGFA }}{\text { specific activity FFA }}=1-\mathrm{e}^{-\mathbf{t t}}
$$


TABLE V

Specific Activity of Carbonyl-Carbon of Acetoacetate

\begin{tabular}{lccc}
\hline Subject & $\begin{array}{c}\text { VLDL } \\
\text { TGFA }\end{array}$ & \multicolumn{2}{c}{$\begin{array}{c}\text { Specific } \\
\text { activity* }\end{array}$} \\
\hline & umoles/ml & $210 \ddagger$ & $240 \ddagger$ \\
G. T. & 1.8 & 88 & 80 \\
G. I. & 3.0 & 112 & 83 \\
G. S. & 6.3 & 74 & 93 \\
M. G. & 9.5 & 90 & 98 \\
D. A. & 27.4 & 86 & 86 \\
Mean & & 90 & 88 \\
\hline
\end{tabular}

* Expressed as per cent of specific activity of FFA in hepatic venous blood plasma $\times 4 / 17$.

$\ddagger$ Min of infusion of palmitate-1-14 C.

\section{DISCUSSION}

These studies indicate that the splanchnic region accounts for a larger fraction of FFA removed from the blood in man than suggested from earlier work $(23,24)$. With the constant infusion technique, it has been possible to correct net uptake of FFA for FFA entering hepatic venous blood from the splanchnic region and also to estimate the quantity of these FFA which are taken up in the liver. We are unable to determine the magnitude of the error introduced in calculation of this portion of splanchnic uptake; however, since it usually accounts for a small part of the total, its influence on calculated fluxes of FFA through various pathways must be small.

Splanchnic release of FFA apparently can vary, over a wide range, not closely related in different subjects to over-all rate of fat mobilization from adipose tissue. Variability of the fraction of transported FFA taken up from the blood in the splanchnic region was also shown; in our hyperlipemic subjects this fraction was greater than one-half. These factors together with net inflow transport, are the main determinants of splanchnic uptake.

The large uptake of FFA in the splanchnic region has suggested that, as in muscle, they may be the prime substrate of oxidative metabolism (2). It has long been known that the R.Q. is low in perfused liver (25), but data permitting quantitative assessment of the contribution of FFA to splanchnic oxygen consumption have not

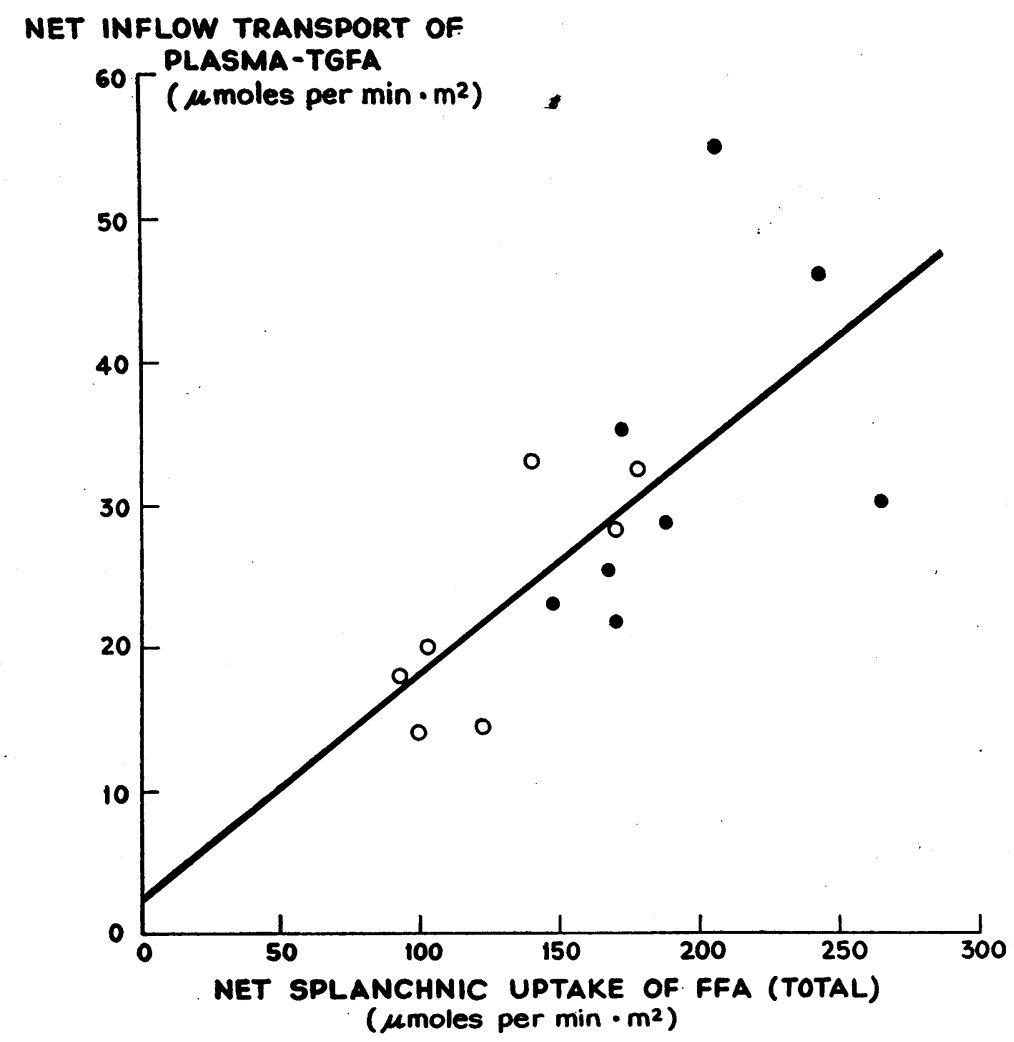

FIGURE 6 Relation between splanchnic uptake of FFA (entering in arterial and portal venous blood) and net inflow transport of TGFA into hepatic venous blood in normolipemic (open circles) and hyperlipemic subjects (closed circles). Regression coefficient $=0.159, r=0.70, P<0.01$. 


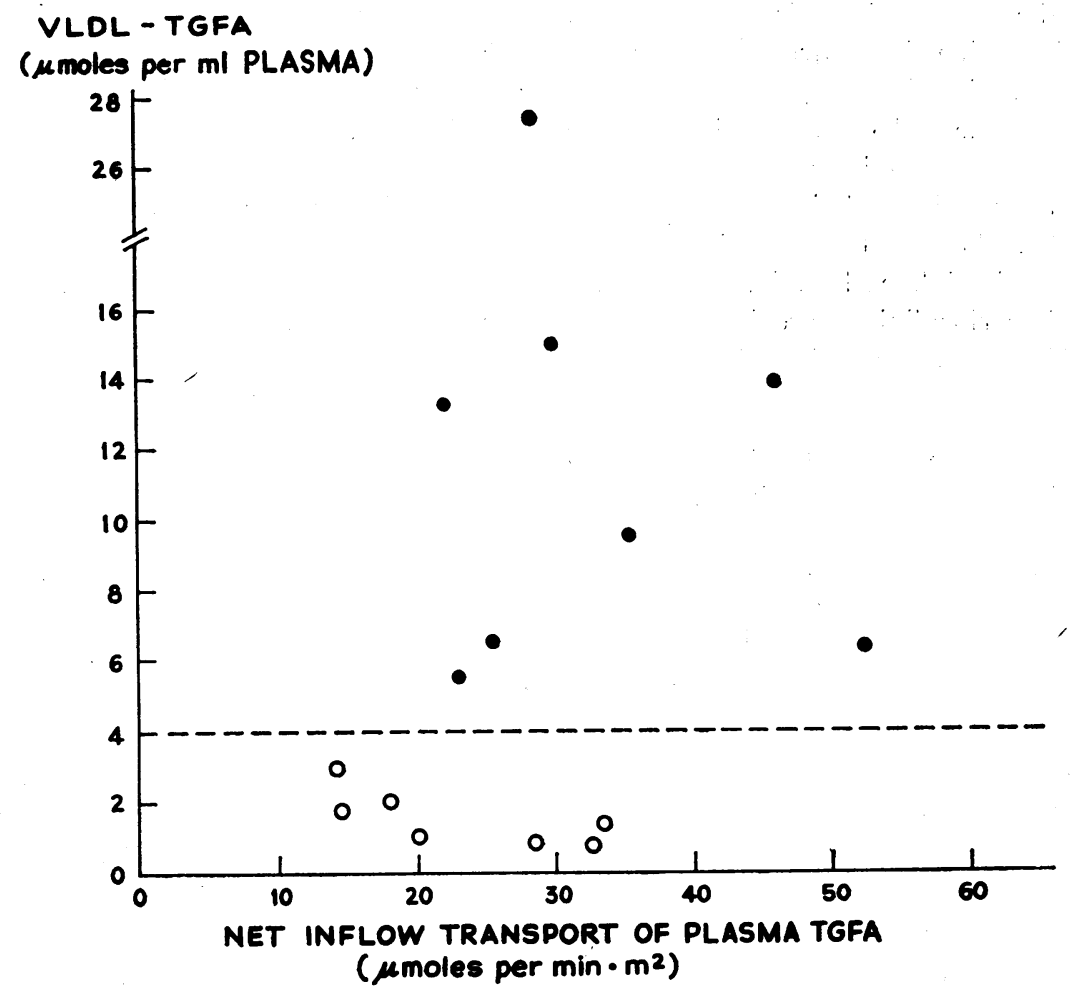

Figure 7 Relation between net inflow transport and arterial concentration of VLDL-TGFA in normolipemic (open circles) and hyperlipemic subjects (closed circles). The dashed line indicates upper limit of normal concentration of VLDL-TGFA.

been available. It was not possible to make a direct and unambiguous measurement even with the present approach because of the complicated fate of acyl CoAcarbon in a gluconeogenic tissue such as the liver. Isotopic equilibration of this carbon with other precursors of oxaloacetate (chiefly amino acids) results in the appearance of the ${ }^{\mu} \mathrm{C}$ in other compounds, mainly glucose. We have been able to account for up to $2 \%$ of palmitate${ }^{14} \mathrm{C}$ in extracellular glucose after $2 \mathrm{hr}$ of constant infusion into normolipemic subjects. ${ }^{1}$ This would amount to about $5 \%$ of that taken up in the splanchnic region. Without quantitative values for this and similar processes, it is clear that conversion to $\mathrm{CO}$, of ${ }^{16} \mathrm{C}$ in palmitate or any other compound entering the tricarboxylic acid cycle in the liver cannot provide reliable information concerning the extent of oxidation. It is for this reason that we made the estimates shown in Table VI. The corrected value for splanchnic R.Q. depends upon unambiguous calculation of oxygen utilized during conversion of fatty acids to ketone bodies and an assumed value for fixation of $\mathrm{CO}_{2}$ in urea. The latter value is not expected to be much in error for subjects with known

${ }^{1}$ Wolfe, B. M., and R. J. Havel. Unpublished data. intake of protein. The mean value of 0.65 for corrected R.Q. provides strong evidence that fatty acids are the most important source of $\mathrm{CO}_{2}$ produced in the tricarboxylic acid cycle. The value may be expected to err slightly on the low side because of neglect of extramitochondrial oxygen-utilizing reactions such as those concerned with hydroxylations. The calculations shown in Table VI suggest that normally about two-thirds of the FFA taken up in the splanchnic region are oxidized with approximately equal fractions converted to ketone bodies and to $\mathrm{CO}_{2}$ and water. Of the remaining one-third, about half is secreted as VLDL-TGFA while the remainder presumably is stored in hepatic lipids. In hyperlipemic subjects, a smaller fraction of FFA was oxidized to ketones. This difference could not be related to their increased fat stores, since neither fractional conversion of FFA to ketones nor splanchnic production of ketones correlated with ponderal index. The greater splanchnic consumption of oxygen in hyperlipemic subjects did not suffice to balance the increased uptake of FFA. About two-thirds of the FFA which escaped oxidation in these subjects were apparently stored and one-third secreted in VIDL-TGFA. The extent of storage did not appear to correlate with body fat content as estimated from 
ponderal index and the reasons for this difference between control and hyperlipemic subjects are obscure. We also have no explanation for the greater fractional extraction of FFA in the splanchnic region in the latter group, which was the major factor underlying their greater splanchnic uptake of FFA. Possibly other metabolic abnormalities known to exist in subjects with endogenous and mixed hyperlipemia, such as insulin resistance and hyperinsulinism, are involved. The larger release of FFA from the extrahepatic splanchnic region in hyperlipemic subjects might be expected to relate to their greater store of adipose tissue in this area, but correlation between estimated release and pondral index was not shown. Variability in distribution of adipose tissue between mesentery and omentum and other regions may obscure such a relationship.

Our calculations of transport of VLDL-TGFA depend upon the extent to which precurors other than FFA are present. From the demonstrated precursor-product relationship and the over-all concordance between chemi-
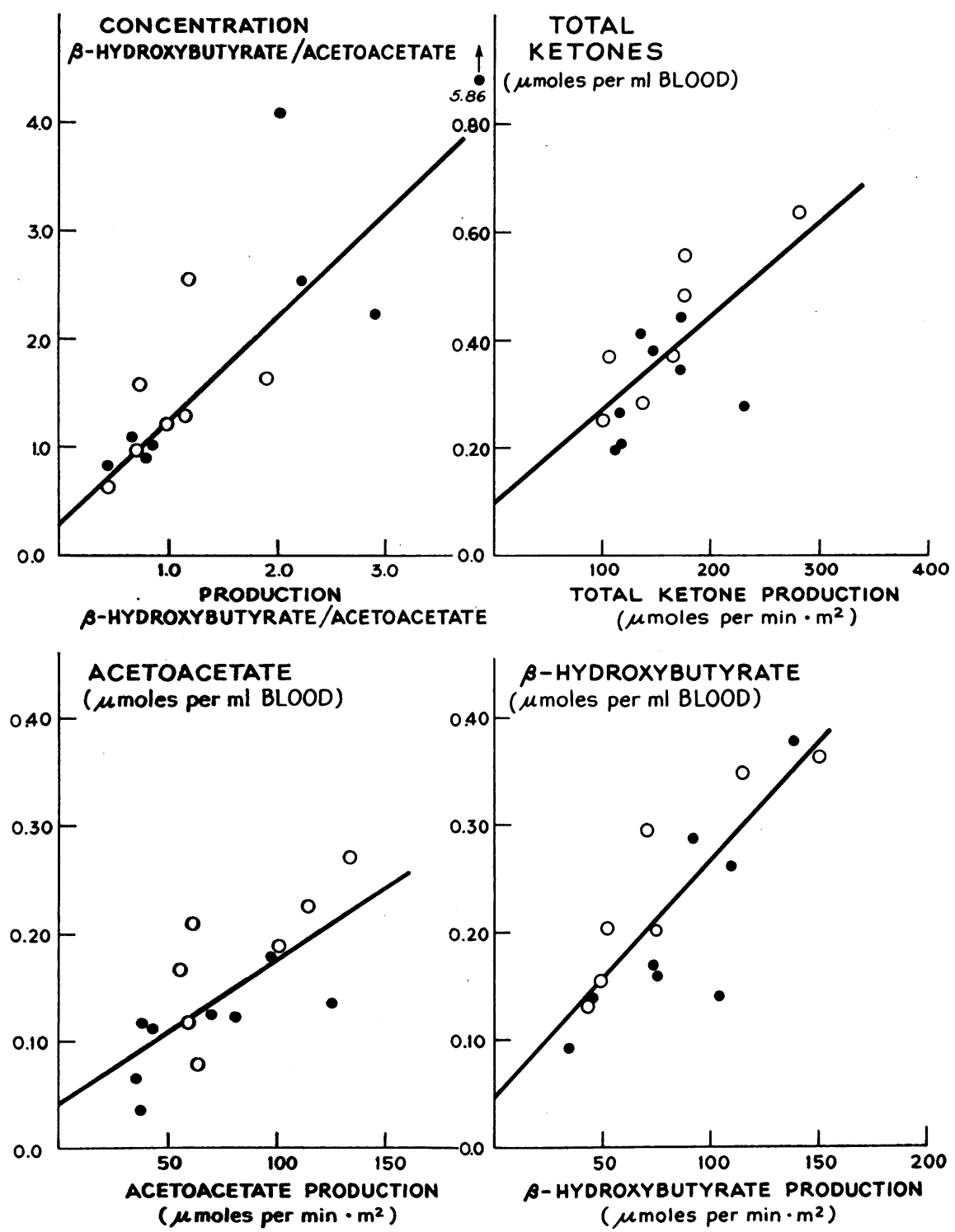

FIGURE 8 Relation between splanchnic production and arterial values for ketone concentrations and ratios in normolipemic (open circles) and hyperlipemic (closed circles) subjects. Regressions : upper left, coefficient $=1.21, r=0.86, P<0.001$; upper right, coefficient $=0.00172, r=0.68, P<0.01$; lower left, coefficient $=0.00135, r=0.72, P$ $<0.01$; lower right, coefficient $=0.00218, r=0.83, P<0.001$. 
TABLE VI

Estimated Splanchnic Utilization of Free Fatty Acids

\begin{tabular}{|c|c|c|c|c|c|c|c|}
\hline \multirow[b]{2}{*}{ Subject } & \multirow[b]{2}{*}{$\begin{array}{c}\text { Corrected } \\
\text { R. Q.* }\end{array}$} & \multicolumn{5}{|c|}{ Rates of conversion } & \multirow[b]{2}{*}{$\begin{array}{l}\text { Per cent of FFA- } \\
\text { carbon secreted } \\
\text { in major products }\end{array}$} \\
\hline & & $\begin{array}{l}\text { VLDL- } \\
\text { TGFA }\end{array}$ & $\begin{array}{c}\text { Total } \\
\text { ketones }\end{array}$ & $\begin{array}{c}\mathrm{CO}_{2} \text { attributable } \\
\text { to oxidation } \\
\text { of FFA }\end{array}$ & Sum & Unaccounted & \\
\hline & \multirow{2}{*}{\multicolumn{7}{|c|}{ umoles carbon $/ \min \cdot m^{2}$}} \\
\hline Normolipemic & & & & & & & \\
\hline F. G. & - & 483 & 704 & 775 & 1962 & 948 & 67 \\
\hline L. H. & - & 306 & 404 & 773 & 1483 & 97 & 94 \\
\hline R. R. & - & 554 & 1128 & 761 & 2443 & 557 & 81 \\
\hline G. T. & 0.57 & 342 & 424 & 655 & 1421 & 329 & 81 \\
\hline W. T. & 0.68 & 247 & 704 & 1135 & 2086 & 4 & 100 \\
\hline G. I. & 0.68 & 241 & 548 & 733 & 1522 & 121 & 90 \\
\hline D. C. & - & 565 & 652 & 554 & 1771 & 629 & 74 \\
\hline Mean & 0.643 & 391 & 652 & 775 & 1812 & 383 & 83.9 \\
\hline SEM & 0.037 & 53.0 & 92.1 & 80.2 & 141.6 & 129 & 4.36 \\
\hline \multicolumn{8}{|c|}{ Hyperlipemic } \\
\hline C. S. & - & 435 & 588 & 713 & 1736 & 1122 & 61 \\
\hline A. F. & 0.55 & 785 & 448 & 1150 & 2383 & 1747 & 58 \\
\hline E. J. & 0.49 & 515 & 536 & 1060 & 2111 & 2399 & 47 \\
\hline G. S. & 0.77 & 936 & 460 & 918 & 2314 & 1186 & 66 \\
\hline M. G. & 0.58 & 600 & 688 & 1030 & 2318 & 582 & 80 \\
\hline A. S. & 0.76 & 391 & 692 & 758 & 1841 & 677 & 73 \\
\hline D. A. & 0.63 & 490 & 460 & 1365 & 2315 & 885 & 72 \\
\hline A. Fr. & 0.82 & 373 & 920 & 1113 & 2406 & 504 & 83 \\
\hline Mean & 0.657 & 565 & 599 & 1013 & 2178 & 1137 & 67.5 \\
\hline SEM & 0.048 & 70.6 & 57.5 & 75.50 & 91.05 & 229.6 & 4.23 \\
\hline$P$ & NS & NS & NS & NS & NS & $<0.05$ & $<0.05$ \\
\hline
\end{tabular}

* $\quad \mathrm{CO}_{2}$ produced $+150 \mu \mathrm{moles} / \mathrm{min} \cdot \mathrm{m}^{2}$

$\mathrm{O}_{2}$ consumed $-\mathrm{O}_{2}$ attributable to production of ketones

$\ddagger$ Oxygen not used for ketogenesis assumed to be used for complete oxidation of fatty acids.

cal and radiochemical estimates of transport of VLDLTGFA, it seems clear that FFA are by far the most important precursors in our normolipemic subjects. The evidence for this is less compelling for the hyperlipemic subjects. Two potential hepatogenous sources of VLDLTGFA other than FFA must be considered. One is local synthesis from nonlipid precursors. This seems most unlikely since our subjects were postabsorptive and splanchnic R.Q. was similar (mean value 0.65 ) to that of the normolipemics. This value is incompatible with substantial de novo synthesis of fatty acids. Additionally, recent studies in subjects with endogenous hyperlipemia infused intravenously with glucose ${ }^{14} \mathrm{C}$ and palmitate- ${ }^{8} \mathrm{H}$ and given substrate loads of oral glucose have shown that, even during alimentary hyperglycemia, fatty acids synthesized from glucose contribute only about $10 \%$ of fatty acids in newly synthesized plasma triglycerides (26). A second potential source of VLDL-TGFA in our hyperlipemic subjects is preformed fatty acids stored in hepatic lipids. This situation may obtain in insulindeficient, ketotic diabetic dogs with grossly fatty livers. In such animals, it has been found that only slightly more than half of the ketones produced by the liver are derived from FFA taken up from the blood (6), so that the fatty acyl CoA pool leading to ketogenesis may be derived in part from other sources. This pool could also contribute to synthesis of TGFA in the extramitochondrial compartment of the cell. In our hyperlipemic subjects, this was not the case (Table V), although they did appear to store more FFA in hepatic lipids than the normolipemics (Table VI). Current information concerning formation of VLDL-TGFA suggests that they arise in the smooth endoplasmic reticulum, the extramitochondrial site of esterification of fatty acids, and that they remain enclosed within a tubular system until they are secreted from the parenchymal cell (27). Therefore, in the absence of evidence for separate pools leading to esterification and oxidation of fatty acids, it seems 
TABLE VII

Net Splanchnic Transport of Carbohydrates

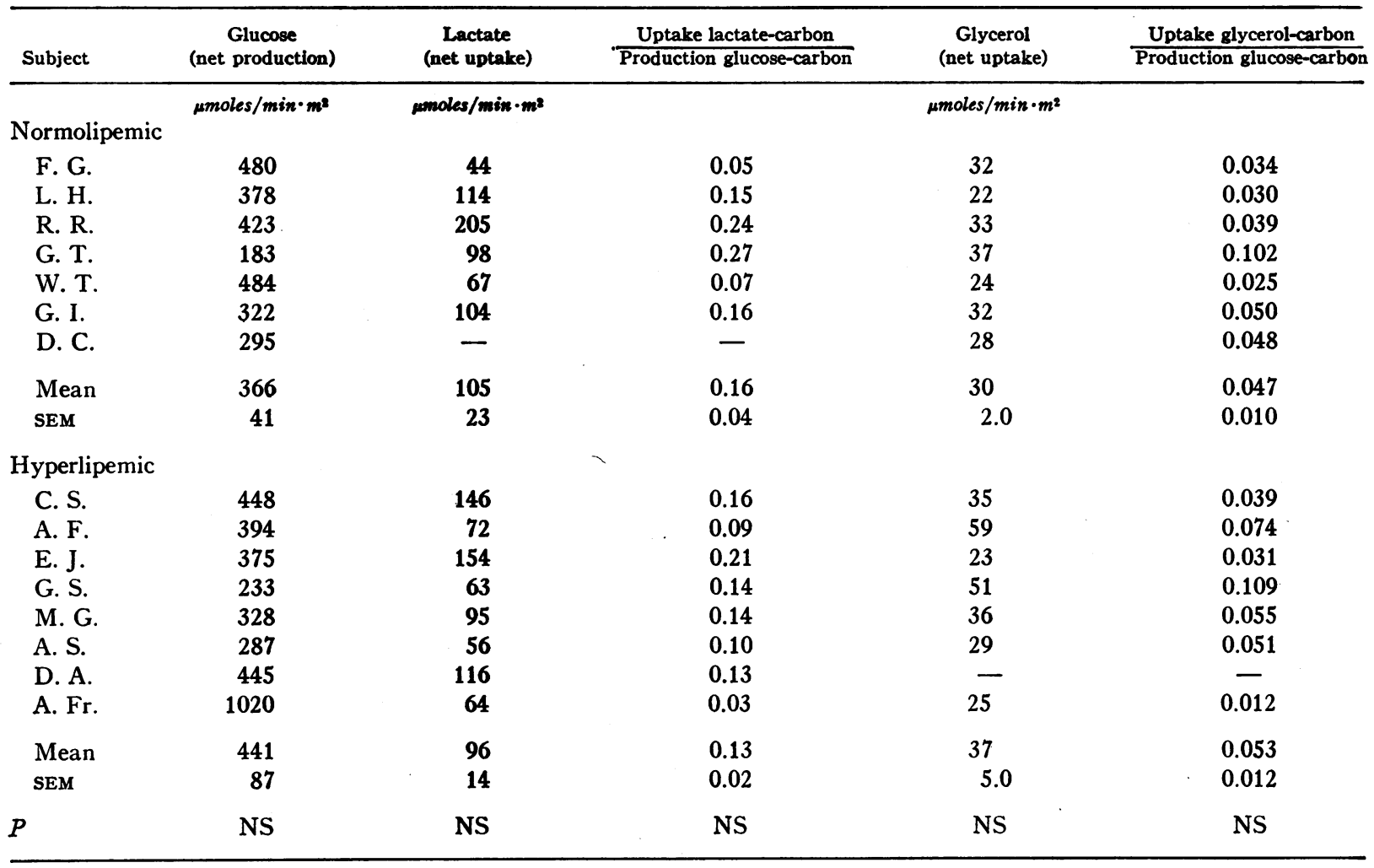

likely that in normolipemic and hyperlipemic subjects, FFA account for $90 \%$ or more of TGFA secreted in VLDL. It is possible, however, that pools of fatty acyl CoA leading to esterification and oxidation are not in equilibrium, so that stored lipid can contribute only to VLDL precursors. It is also conceivable that stored triglycerides are incorporated into VLDL precursors without hydrolysis. The following considerations suggest that stored hepatic lipid, not equilibrating with incoming FFA during the $4 \mathrm{hr}$ of study, contributes relatively little to VLDL-TGFA in our hyperlipemic subjects. The specific activity of VLDL-TGFA was still increasing at a linear rate in these subjects at the end of the study, even in the five whose specific activity had reached a level close to half that of FFA in hepatic venous blood plasma. Furthermore, if unlabeled precursors contributed as much as $20 \%$ of secreted VLDLTGFA, the values (Table IV) for inflow transport of TGFA calculated from isotopic equilibration (which are predicated upon the assumption that FFA are the absolute precursor) should have been substantially lower than those calculated from fractional conversion of FFA to TGFA. The values, in fact, agreed closely in five hyperlipemic subjects, and the values from iso- topic equilibration were higher in two of the three others.

Some VLDL, synthesized in intestinal mucosa, enter the blood via the thoracic duct in the postabsorptive state (28). Since these are thought to be derived primarily from biliary phospholipids (29), their TGFA might contain appreciable ${ }^{14} \mathrm{C}$. The agreement between values for inflow transport of TGFA derived from isotopic equilibration and those based upon fractional conversion of FFA to TGFA in the splanchnic region also provides evidence that this source of VLDL is a minor one in postabsorptive humans.

A major conclusion that emerges from our estimates of triglyceride transport from the liver is that a defect in extrahepatic mechanisms for removal of TGFA exists in at least four of our six subjects with endogenous hyperlipemia. A greater inflow transport of TGFA may have contributed to the magnitude of the abnormality in A.F. and G.S. (Table IV and Fig. 7). Triglyceride concentration was also related closely to efficiency of removal in the normolipemic group, as reflected in the close correlation between plasma content and turnover time. The normolipemic subjects were on the whole younger and thinner than the hyperlipemics. 
However, neither age nor adiposity appears to be related to inflow transport or plasma level of triglycerides in the normolipemic group. A defect in removal also appears to be present in our single subjects with familial dysbetalipoproteinemia and mixed hyperlipemia. Defects in removal might be expected in these latter two subjectsin dysbetalipoproteinemia because of abnormal lipoprotein carrier (30) and in mixed hyperlipemia because removal of exogenous triglycerides also seems to be impaired (31). The conclusion that a defect in removal is present in the more common endogenous hyperlipemia is more surprising, since no such defect for exogenous TGFA or in the lipoprotein lipase system has been demonstrated (27). A similar conclusion has been reported recently by Quarfordt, Frank, Shames, Berman, and Steinberg from estimates of transport of VLDLTGFA derived from multicompartmental analysis of ${ }^{14} \mathrm{C}$ in FFA and VLDL-TGFA after pulse-injection of palmitate $-{ }^{14} \mathrm{C}$ into normolipemic subjects and subjects with endogenous hyperlipemia (32). Other studies, however, have led to the opposite conclusion. Reaven, Hill, Gross, and Farquhar have estimated the turnover rate of VI,DL-TGFA from the slope of the die-away curve in triglycerides after injecting labeled glycerol (33) and have interpreted their results to indicate that removal is normally readily saturable. Elsewhere, we have compared their results with ours $(1,34)$. These comparisons show that the two methods seem to give similar results at high triglyceride levels but that our approach provides considerably higher values at normal levels. This comparison and other data have led us to conclude that the method used by these workers underestimates transport of VLDL-TGFA in the normal range. Thus, we have found that rates of inflow transport of TGFA may be closely similar in normolipemic and hyperlipemic subjects whose concentrations of VLDL-TGFA differ by as much as fortyfold (Fig. 7). Another method which has been employed extensively to measure transport of plasma TGFA in man was proposed by Ryan and Schwartz (35). Our results permit direct comparison with this method, which depends upon the accumulation of isotope in plasma TGFA during constant infusion of labeled precursor. This comparison has shown that the method proposed by Ryan and Schwartz and used especially by Sailer, Sandhofer, and Braunsteiner (36) underestimates transport by an average of 40

\section{NET SPLANCHNIC PRODUCTION OF GLUCOSE ( $\mu$ moles per $\mathrm{min} \cdot \mathrm{m}^{2}$ )}

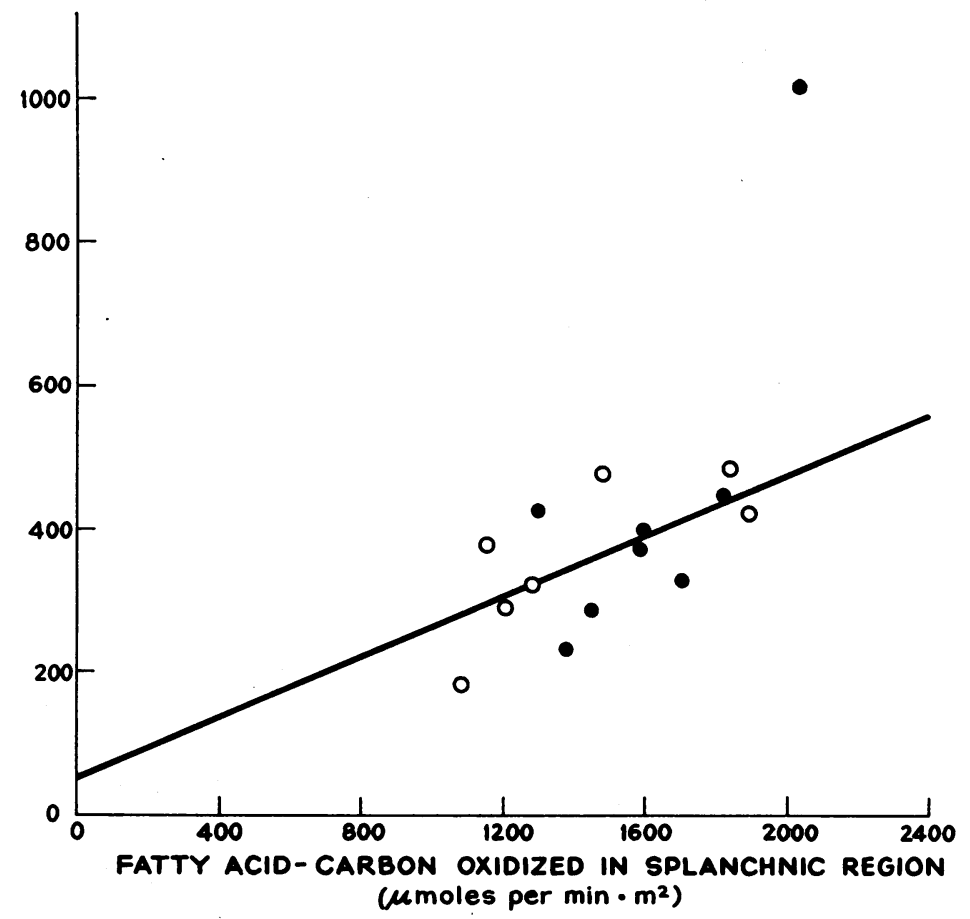

FIGURE 9 Relation between oxidation of FFA and net production of glucose in splanchnic region in normolipemic (open circles) and hyperlipemic (closed circles) subjects. Regression coefficient $=0.208, r=0.60,0.05>P>0.02$ (hyperlipemic subject A. Fr., who had mild fasting hyperglycemia and unusually high production rate, omitted). 
$50 \%(1,34)$. This results from: (a) neglect of removal of labeled TGFA from the plasma during the period of measurement; and (b) assumption that peripheral venous or arterial FFA are in equilibrium with the precursor pool of VLDL-TGFA in liver. It should be emphasized that the estimates of transport that we have made here apply only to the postabsorptive state in subjects on ordinary diets. Whether transport responds differently in certain hyperlipemic subjects to various maneuvers, such as a low fat, high carbohydrate diet, is not certain (32). It is, however, pertinent to point out here that a decrease in efficiency of removal would result in greater "sensitivity" to stimuli increasing inflow transport from liver, when absolute changes in concentration are the index.

Another important conclusion that can be made from our measurements of transport of TGFA is that rate of hepatic secretion of VLDL is a direct and apparently linear function of splanchnic uptake of FFA. This supports earlier qualitative studies as well as similar quantitative studies in the dog (6). Although over-all inflow transport of FFA was not increased in our hyperlipemic subjects, transport of TGFA into the blood was increased in proportion to increased splanchnic uptake of FFA. Different responses to various stimuli affecting transport of FFA, such as insulin and fat-mobilizing hormones, could also intensify the hyperlipemia. These may be of major importance in therapeutic maneuvers even though they may not necessarily be directed against the primary (presumably genetic) defect. Altered hepatic metabolism of FFA can also affect inflow transport of TGFA as demonstrated with the present method in von Gierke's disease (37) and with administration of ethanol (38).

This study has also provided some new information concerning the dynamics of ketone metabolism in man. As expected, the concentration of ketones in blood was shown to be related directly to net splanchnic production. However, increasing ketone levels during the study were not related to increased rates of production in our control subjects. This indicates that removal of ketones may become less efficient with more prolonged fasting, in agreement with recent studies in dogs $(6,39)$. The direct relationship between ketone concentration (but not production) and ponderal index suggests that decreased ketogenesis may not entirely explain the decreased tendency to ketosis observed in obesity (40). Our data are insufficient to establish that a sex difference exists in ketogenesis. The redox couple, $\beta$-hydroxybutyrate-acetoacetate, has been thought to provide a mechanism for equilibrating redox state of pyridine nucleotides in hepatic and extrahepatic tissues. Our observations, which suggest that the blood reflects the situation within the liver and other studies (41) show- ing that fractional uptake of these two metabolites differs in peripheral tissues, are in keeping with this concept.

Our observations on net splanchnic uptake of lactate and glycerol and production of glucose are in agreement with published data $(23,42,43)$. Other studies have shown that, in subjects fasted overnight, only about half of the glucose secreted can be derived from gluconeogenic precursors. ${ }^{1}$ In spite of this, we found that glucose production correlated with estimated splanchnic oxidation of FFA. Although the extent to which glycogenolysis contributes to blood glucose in each subject is not known, this is the first direct observation, under physiologic conditions, to support the relationship (44) between gluconeogenesis and ketogenesis which has been observed in several model systems.

\section{ACKNOWLEDGMENTS}

We thank B. Carlander, C. Drakes Benjamin, D. Gobat, and B. Nord for expert technical assistance.

These studies were supported by U. S. Public Health Service Grant HE-06285 and General Clinical Research Center. Grant 2 MO1 RR00079-08.

\section{REFERENCES}

1. Havel, R. J. 1968. Triglyceride and very low density lipoprotein turnover. Proceedings of the 1968 Deuel Conference of Lipids. G. Cowgil, D. L. Estrich, and P. D. Wood, editors. U. S. Government Printing Office, Washington, D. C. 115.

2. Fritz, I. B. 1961. Factors influencing the rates of longchain fatty acid oxidation and synthesis in mammalian systems. Physiol. Rev. 41: 52.

3. Friedberg, S. J., R. F. Klein, D. L. Trout, M. D. Bogdonoff, and E. H. Estes, Jr. 1961. The incorporation of plasma free fatty acids into plasma triglycerides in man. J. Clin. Invest. 40: 1846.

4. Havel, R. J. 1961. Conversion of plasma free fatty acids into triglycerides of plasma lipoprotein fractions in man. Metabolism. 10: 1031.

5. Havel, R. J., J. M. Felts, and C. M. Van Duyne. 1962. Formation and fate of endogenous triglycerides in blood plasma of rabbits. J. Lipid Res. 3: 297.

6. Basso, L. V., and R. J. Havel, 1970. Hepatic metabolism of free fatty acids in normal and diabetic dogs. J. Clin. Invest. 49: 537.

7. Sperry, W. M., and J. Webb. 1950. A revision of the Schoenheimer-Sperry method for cholesterol determination. J. Biol. Chem. 187: 97.

8. Stewart, C. P., and E. B. Hendry. 1935. The phospholipins of blood. Biochem. J. 29: 1683.

9. Carlson, L. A. 1963. Determination of serum triglycerides. J. Atheroscler. Res. 3: 334.

10. Lowry, O. H., N. J. Rosebrough, A. L. Farr, and R. J. Randall. 1951. Protein measurement with the Folin phenol reagent. J. Biol. Chem. 193: 265.

11. Saifer, A., and S. Gerstenfeld. 1958. The photometric microdetermination of blood glucose with glucose oxidase. J. Lab. Clin. Med. 51: 488. 
12. Chernick, S. S. 1969. Determination of glycerol in acyl glycerols. In Methods in Enzymology. J. Lowenstein, editor. Academic Press Inc., New York. 14: 627.

13. Loomis, M. E. 1961. An enzymatic fluorometric method for the determination of lactic acid in serum. J. Lab. Clin. Med. 57: 966 .

14. Gornall, A. G., C. J. Bardawill, and M. M. David. 1949. Determination of serum proteins by means of the biuret reaction. J. Biol. Chem. 177: 751.

15. Havel, R. J., A. Naimark, and C. F. Borchgrevink. 1963. Turnover rate and oxidation of free fatty acids of blood plasma in man during exercise: studies during continuous infusion of plamitate-1-C $\mathrm{C}^{\mathbf{1 4}}$. J. Clin. Invest. 42: 1054.

16. Van Slyke, D. D., and J. M. Neill. 1924. The determination of gases in blood and other solutions by vacuum extraction and manometric measurement. J. Biol. Chem. 61: 523.

17. Buhler, D. R. 1962. A simple scintillation counting technique for assaying $\mathrm{C}^{14} \mathrm{O}_{2}$ in a Warburg flask. Anal. Biochem. 4: 413.

18. Ketterer, S. G., B. D. Wiegand, and E. Rapaport. 1960. Hepatic uptake and biliary excretion of Indocyanine green and its use in estimation of hepatic blood flow in dogs. Amer. J. Physiol. 199: 481.

19. Mainland, D. 1963. Elementary Medical Statistics. W. B. Saunders Company, Philadelphia. 2nd edition. 283.

20. Zilversmit, D. B. 1960 . The design and analysis of isotope experiments. Amer. J. Med. 29: 832.

21. Myers, J. D. 1947. The hepatic blood flow and splanchnic oxygen consumption of man-their estimation from urea production or bromsulphalein excretion during catheterization of the hepatic veins. J. Clin. Invest. 26: 1130.

22. Walser, M., and L. J. Bodenlos. 1959. Urea metabolism in man. J. Clin. Invest. 38: 1617.

23. Borchgrevink, C. F., and R. J. Havel. 1963. Transport of glycerol in human blood. Proc. Soc. Exp. Biol. Med. 113: 946 .

24. Carlson, L. A., and L. G. Ekelund. 1963. Splanchnic production and uptake of endogenous triglycerides in the fasting state in man. J. Clin. Invest. 42: 714.

25. Blixenrone-M $\phi 1$ ler, N. 1938. Respiratorischer stoffwechsel and ketonkorperbildung der leber. Hoppe-Seyler's Z. Physiol. Chem. 252: 117.

26. Sandhofer, F., K. Bolzano, S. Sailer, and H. Braunsteiner. 1969. Quantitative untersuchungen über den einbau von plasmaglucose-kohlenstoff in plasmatriglyceride und die veresterungsrate von freien fettsäuren des plasmas zu plasmatriglyceriden während oraler zufuhr von glucose bei primärer kohlenhydratinduzierter hypertriglyceridāmie. Klin. Wochenschr. 47: 1086.

27. Havel, R. J. 1969. Pathogenesis, differentiation and management of hypertriglyceridemia. Advan. Intern. Med. 15: 117 .

28. Ockner, R., F. B. Hughes, and K. J. Isselbacher. 1969. Very low-density lipoproteins in intestinal lymph: origin, composition and role in lipid transport in the fasting state. J. Clin. Invest. 48: 2079.

29. Baxter, J. H. 1966. Origin and characteristics of endogenous lipid in thoracic duct lymph in rats. J. Lipid Res. 7: 158.

30. Brown, V. W., R. I. Levy, and D. S. Fredrickson. 1969. A comparative study of the very low density lipoproteins in normal subjects and patients with types III, IV and V hyperlipoproteinemia. Circulation. 40 (Suppl. III) : 4 .

31. Fredrickson, D. S., R. I. Levy, and R. S. Lees. 1967. Fat transport in lipoproteins-an integrated approach to mechanisms and disorders. N. Engl. J. Med. 276: 34.

32. Quarfordt, S. H., A. Frank, D. M. Shames, M. Berman, and D. Steinberg. 1970. Turnover of triglycerides in very low density lipoproteins (VLDL) in hyperlipoproteinemia. Clin. Res. 18: 187.

33. Reaven, G. M., D. B. Hill, R. C., Gross, and J. W. Farquhar. 1965. Kinetics of triglyceride turnover of very low density lipoproteins of human plasma. J. Clin. Invest. $44: 1826$.

34. Havel, R. J. 1969. Metabolism of plasma triglycerides. Proceedings of the Second International Symposium on Atherosclerosis. Springer-Verlag, New York. In press.

35. Ryan, W. G., and T. B. Schwartz. 1965. Dynamics of plasma triglyceride turnover in man. Metabolism (Clin. Exp.). 15: 1243.

36. Sailer, S., F. Sandhofer, and H. Braunsteiner. 1966. Umsatzraten für freie fettsäuren und triglyceride im plasma bei essentieller hyperlipāmie. Klin. Wochenschr. 44: 1032

37. Havel, R. J., E. O. Balasse, H. E. Williams, J. P. Kane, and N. Segel. 1969. Splanchnic metabolism in von Gierke's disease (glycogenosis type I). Trans. Ass. Amer. Physicians Philadelphia. 82: 305.

38. Wolfe, B. M., R. J. Havel, E. B. Marliss, J. P. Kane, and J. Seymour. 1969. Effects of ethanol on splanchnic metabolism in healthy men. J. Clin. Invest. 49: 104a.

39. Balasse, E. O., and R. J. Havel. 1970. Turnover rate and oxidation of ketone bodies in normal and diabetic dogs. Diabetologia. 6: 36.

40. Bloom, W. L. 1962. Fasting ketosis in obese men and women. J. Lab. Clin. Med. 59: 604.

41. Rudolph, W., D. Maas, J. Richter, F. Hasinger, H. Hofmann, and P. Dohrn. 1965. Über die bedeutung von acetatacetat und $\beta$-hydroxybutyrat im stoffwechsel des menschlichen herzens. Klin. Wochenschr. 43: 445.

42. Myers, J. D. 1950. Net splanchnic glucose production in normal man and in various disease states. J. Clin. Invest. 29: 1421 .

43. Tygstrup, N., K. Winkler, and F. Lundquist. 1965. The mechanism of the fructose effect on the ethanol metabolism of the human liver. J. Clin. Invest. 44: 817.

44. Krebs, H. A. 1966. Bovine ketosis. Vet. Rec. 78: 187. 